\title{
A historical review of multiple system atrophy with a critical appraisal of cellular and animal models
}

\author{
David J. Marmion ${ }^{1}$ (i) $\cdot$ Wouter Peelaerts ${ }^{2}\left[\right.$ ] Jeffrey H. Kordower ${ }^{3}$ (i)
}

Received: 6 July 2021 / Accepted: 15 September 2021 / Published online: 6 October 2021

(c) The Author(s) 2021

\begin{abstract}
Multiple system atrophy (MSA) is a progressive neurodegenerative disorder characterized by striatonigral degeneration (SND), olivopontocerebellar atrophy (OPCA), and dysautonomia with cerebellar ataxia or parkinsonian motor features. Isolated autonomic dysfunction with predominant genitourinary dysfunction and orthostatic hypotension and REM sleep behavior disorder are common characteristics of a prodromal phase, which may occur years prior to motor-symptom onset. MSA is a unique synucleinopathy, in which alpha-synuclein (aSyn) accumulates and forms insoluble inclusions in the cytoplasm of oligodendrocytes, termed glial cytoplasmic inclusions (GCIs). The origin of, and precise mechanism by which aSyn accumulates in MSA are unknown, and, therefore, disease-modifying therapies to halt or slow the progression of MSA are currently unavailable. For these reasons, much focus in the field is concerned with deciphering the complex neuropathological mechanisms by which MSA begins and progresses through the course of the disease. This review focuses on the history, etiopathogenesis, neuropathology, as well as cell and animal models of MSA.
\end{abstract}

Keywords Multiple system atrophy $\cdot$ Alpha-synuclein $\cdot$ Oligodendrocytes $\cdot$ Glioneuronal degeneration $\cdot$ Pathology $\cdot$ Animal models

\section{Introduction}

\section{Historical review of MSA}

Preamble: On behalf of all authors, we are honored to participate in a special issue honoring 90th birthday of Professor Kurt Jellinger whose remarkable career has educated us greatly in the area of neurodegenerative diseases. What is especially true, is that Professor Jellinger has unlocked many of the mysteries surrounding human disease and, in many instances, has compiled this information in cogent understandable papers allowing for simplified understanding of complex diseases. We are grateful and wish him well.

Jeffrey H. Kordower

jeffrey.kordower@asu.edu

1 Parkinson's Disease Research Unit, Department of Neurobiology, Barrow Neurological Institute, Phoenix, AZ, USA

2 Laboratory for Neurobiology and Gene Therapy, Department of Neurosciences, Leuven Brain Institute, KU Leuven, Leuven, Belgium

3 ASU-Banner Neurodegenerative Disease Research Center, Biodesign Institute, Arizona State University, Tempe, AZ, USA
Multiple system atrophy (MSA) is a rare, universally fatal, and progressive neurodegenerative disease, clinically characterized by parkinsonian, cerebellar, and dysautonomic features in any combination. The predominant disease feature may evolve as the disease progresses, and which ultimately may or may not encompass all aspects of the disease symptomology. Previously, the disease we now call MSA was separated into three distinct diseases based on symptomatology including Shy-Drager syndrome as well as neuropathology including striatonigral degeneration (SND) and olivopontocerebellar atrophy (OPCA).

The first clinically reported cases of MSA were published in 1900, when Dejerine and Thomas described two cases of adult-onset (42 and 52 years of age) sporadic ataxia, presenting with dysarthria, akinesia, rigidity, and brisk leg reflexes. The patients developed urinary incontinence and probable postural hypotensive symptoms. Both patients died three years following diagnosis (Dejerine 1900; Quinn 1989). Pathological analysis of these cases revealed degeneration 
in the olives, pons, and cerebellum creating the term olivopontocerebellar atrophy. Of note, the striatum and substantia nigra were neither examined nor commented on, so the presence of degeneration in these areas is unknown in these cases.

In 1925, Bradbury and Eggleston published a report of three middle-aged men $(36,47$, and 60$)$ who presented with postural hypotension along with anhidrosis and impotence, for the first time suggesting the existence of orthostatic hypotension $(\mathrm{OH})$ of an idiopathic origin (Bradbury and Eggleston 1925). In the following years, reports were made associating autonomic failure with parkinsonian features, such as publications by Langston and Young where middleaged men $(56,43)$ had a history of autonomic failure followed by parkinsonism, antecollis, and husky uncontrollable speech (Langston 1936).

In 1960, Shy and Drager saw four cases and reported "a neurological syndrome associated with orthostatic hypotension", with all cases having marked autonomic dysfunction, slurred speech, impaired coordination, and tremors in the hands at rest. In addition, pyramidal signs and reduced facial expressions were noted. The patients died 5-7 years following disease, and post-mortem evaluation showed cell loss and/or gliosis throughout the brain, but most prominent in the caudate, putamen, globus pallidus, substantia nigra, olives, pons, locus coeruleus, cerebellum, and intermediolateral cell columns of the spinal cord (Shy and Drager 1960).

In 1960 and 1961, van der Eecken, Adams, and van Bogaert published a series of case reports in which they described pronounced shrinkage and discoloration of the putamen and globus pallidus, as well as depigmentation of the substantia nigra, with the striking disappearance of the small cells of the caudate and putamen (Van der Eecken 1960). The authors went on to describe three patients with sporadic disease presenting with a severe akinetic rigid parkinsonian syndrome with brisk reflexes, cerebellar ataxia, and multiple dysautonomic symptoms. Post-mortem examination revealed striatonigral degeneration that was accompanied with cerebellar, olivary and pontine degeneration. One case reported Lewy bodies in the substantia nigra. It was noted by the authors that the findings did not fit with the classical pathological description of Parkinson's disease (PD) and were indicative of a different pathological entity (Adams et al. 1961). This occurred prior to the levodopa era and thus the degree of clinical response to levodopa was unavailable to differentially diagnose Parkinson's disease from MSA. Many previous cases of striatal pathology described in earlier times were initially believed to be part of the spectrum of PD. As such, in 1930, Messing described the case of a 62-year-old woman who presented with "the classical picture of PD", however, upon pathological examination revealed "total atrophy of the ponto-cerebellar system, partial atrophy of the inferior olives and their connections, marked atrophy of the supero-lateral portions of the cerebellum and of the vermis....and fibrosis of the globus pallidus...together with demyelination of the putamen and the anterior portion of the caudate nucleus... This was certainly a case of Parkinson's disease, with an unusual additional lesion: atrophy of the cerebellar pathways" (Messing 1930).

The distinguished movement disorders specialist Professor Niall Quinn, described clinicians over decades approaching MSA like "blindfolded men examining different parts of an elephant and coming away with different impressions of the nature of the beast" (Quinn 1989). It was not until 1969 that Graham and Oppenheimer united these different parts of the "beast"- olivopontocerebellar atrophy, Shy-Drager syndrome, and striatonigral degeneration - as a single disease, stating "there is a group of progressive neurological conditions, most often arising during middle life, with symptoms and signs of lesions affecting several central nervous structures... what is needed is a general term to cover this collection of overlapping progressive pre-senile multi-system degenerations. We wish to avoid the multiplication of names for 'disease entities' which in fact are merely the expressions of neuronal atrophy in a variety of overlapping combinations. We, therefore, propose to use the term "Multiple System Atrophy" (Graham and Oppenheimer 1969).

Twenty years after uniting these seemingly different clinical manifestations under one name, the key pathological hallmark of MSA was discovered. In 1989, Papp and Lantos used the Gallyas method of silver impregnation to first describe the accumulation of insoluble protein aggregates in the brains of 11 patients previously diagnosed with either striatonigral degeneration, olivopontocerebellar atrophy, or Shy-Drager syndrome. These aggregates resembled neurofibrillary tangles typical of Alzheimer's disease; however, histological methods clearly showed these proteinaceous inclusions were located in the cytoplasm of oligodendroglia (Papp et al. 1989). Thus, the inclusions were named glial cytoplasmic inclusions (GCIs) or Papp-Lantos bodies and represent a pathological hallmark specific to MSA. Subsequent studies have shown that the accumulation of GCIs seem to impact the pathology of MSA, as the degree of the burden of GCIs strongly correlate with the level of neuronal loss and demyelination, and that the formation of GCIs occurs prior to the degeneration of axons or neurons (Papp and Lantos 1994; Ozawa et al. 2004). Later, Spillantini and colleagues showed in a seminal paper in 1998 that alpha-synuclein (aSyn), the major component of Lewy bodies (the pathological hallmark of PD) was also the main constituent of insoluble filamentous glial aggregates found in MSA (Spillantini et al. 1998). This finding provided the first ever pathological link between PD, MSA, and dementia with Lewy bodies, uniting these diseases with a common pathological protein as alpha-synucleinopathies. 


\section{Epidemiology, etiology, and genetics}

MSA is a rare disease with an estimated incidence between 0.6 and 0.7 cases per 100,000 person-years (Bower et al. 1997; Fanciulli and Wenning 2015); however, studies out of Russia and Sweden have stated incidences of 0.1 and 2.4 cases per 100,000 person-years, respectively (Linder et al. 2010; Winter et al. 2010). The estimated prevalence of MSA ranges from 1.9 to 4.9 per 100,000 (Tison et al. 2000), which increases up to 7.8 for those over the age of 40 (Schrag et al. 1999) and reaching 12 per 100,000 after 70 years of age (Chrysostome et al. 2004).

The distribution of pathology allows for stratification into two MSA subtypes, MSA-P; a parkinsonian variant characterized by nigrostriatal and striatonigral degeneration, and MSA-C; a cerebellar variant characterized by olivopontocerebellar atrophy (Wenning et al. 1997). Despite this stratification, pathology is typically not solely restricted to regions defined by one subtype but exists in combination where one variant displays a predominant pathology. A distribution of MSA phenotype has emerged based on data from large patient registries, highlighting a predominance of MSA-P (70-80\% of MSA cases) in North America (May et al. 2007), Europe (Wenning et al. 1994a, b, 1997, 2013), and Korea (Kim et al. 2011), while MSA-C accounts for $67-84 \%$ of cases in Japan (Watanabe et al. 2002; Yabe et al. 2006; Ozawa et al. 2010). Despite this distribution in MSA phenotype, average age of onset remains to be similar throughout North America, Europe, Korea, and Japan, with symptoms emerging in the fifth to sixth decade of life (Saito et al. 1994; Bower et al. 1997; Wullner et al. 2007; Kollensperger et al. 2010; Kim et al. 2011). However, instances of young-onset MSA, where disease onset occurs before 40 years of age, and late-onset MSA variants, with disease onset after 75 years old, have been described (Batla et al. 2018, Fanciulli et al. 2019). Although less common, other subtypes of atypical MSA have been described. In these cases, there is restricted and severe neuropathology accompanied by widespread and high GCI burden that extends beyond the affected site. We will focus on these cases of 'minimal change MSA' and other atypical forms of MSA in a separate section below.

Unlike PD, MSA seems to affect both sexes equally and progresses more rapidly than $\mathrm{PD}$, with a mean survival of 6-9 years following symptom onset (Quinn 1989; Papapetropoulos et al. 2007; Schrag et al. 2008; Wenning et al. 2008; Low et al. 2015). Of note, however, cases of MSA have been reported with survival up to 20 years, while others are extremely rapidly progressing with disease duration as short as 2 years (Watanabe et al. 2002; Petrovic et al. 2012). The specific factors that dictate the speed of survival and deterioration remain unclear; however, early development of severe autonomic failure has been shown to triple the risk for shorter survival (Watanabe et al. 2002; Tada et al. 2007;
O'Sullivan et al. 2008; Figueroa et al. 2014). A prospective, multicenter study showed that patients presenting with pure autonomic failure are at high risk for phenoconverting to manifest CNS synucleinopathy. Specifically, those who phenoconverted to MSA were found to do so faster than LB synucleinopathies, and to have a younger age at onset of autonomic failure, sever bladder/bowel disfunction, preserved olfaction and a cardiac chronotropic response upon tilt $>10$ beats per minute (Kaufmann et al. 2017). Additionally, early falls, early development of combined autonomic and motor features, and severe dysautonomia were recently indicated as unfavorable predictors of survival, while neither sex nor MSA phenotypes were predictors of survival (Glasmacher et al. 2017). Moreover, in one meta-analysis, it was shown that patients who had an onset of MSA later in life had a shorter survival time (Ben-Shlomo et al. 1997).

Like PD, $20-75 \%$ of MSA cases are characterized as having a prodromal phase occurring months to several years prior to motor presentation. In the prodromal phase, nonmotor symptoms include cardiovascular autonomic failure, REM sleep behavior disorder, respiratory disorders, sexual and urogenital dysfunction (Gilman et al. 2008; JecmenicaLukic et al. 2012; Xie et al. 2015; Xia and Postuma 2020). Patients often develop urinary symptoms with the appearance of neurological signs. However, it is estimated that over $20 \%$ of all MSA patients experience sexual or urological symptoms as their initial complaint (Kirchhof et al. 2003), before the occurrence of orthostatic hypotension, autonomic dysfunction or any other central symptoms. At onset these patients develop urinary urgency and incontinence after which urinary retention with voiding difficulties become increasingly apparent (Panicker et al. 2020). This early lower spinal or infrasacral involvement of the urogenital system has led to the hypothesis that a subtype of MSA might exist and and start within the spinal cord degeneration or impairment of sympathetic or parasympathetic nerves innervating these peripheral sites (Panicker et al. 2020). The prodromal involvement of the urogenital system is also reflected by the unusual high frequency of urinary tract infections that are prominent in MSA. More than half of MSA patients suffer from recurrent or chronic UTIs (Papapetropoulos et al. 2007; Jecmenica-Lukic et al. 2012), both before and after the formal diagnosis of MSA. Peripheral infections, including urinary tract infections, can give rise to sepsis and is a frequent cause of death in MSA (Papatsoris et al. 2008).

The precise cause of MSA remains unknown but is likely to be multifactorial, potentially with a combination of genetic predisposition and environmental factors, although currently MSA is generally considered to be a sporadic disease (Fanciulli and Wenning 2015) and a family history of parkinsonism or cerebellar ataxia is considered as a nonsupporting feature in diagnostic criteria (Gilman et al. 2008). However, MSA pedigrees with both autosomal dominant and 
autosomal recessive inheritance patterns have been reported in Europe and Asia (Wullner et al. 2004; Hara et al. 2007; Vidal et al. 2010; Hohler and Singh 2012; Fujioka et al. 2014; Itoh et al. 2014). The prominent difference between the presentation of MSA-P and MSA-C variants across different ethnicities suggests a genetic predisposition towards a specific variant of MSA (Ozawa et al. 2012). A loss-offunction mutation in the gene $C O Q 2$, which encodes for the coenzyme Q10 (COQ10), has been reported in Japanese familial and sporadic MSA cases, as well as other East Asian countries (Multiple-System Atrophy Research Collaboration 2013; Ogaki et al. 2014; Quinzii et al. 2014; Lin et al. 2015; Zhao et al. 2016). This link between V393A mutations in the $C O Q 2$ gene and MSA patients has not been confirmed in European, North American, and Korean populations (Jeon et al. 2014; Schottlaender et al. 2014; Sharma et al. 2014; Ronchi et al. 2016; Sailer et al. 2016). Moreover, decreased levels of COQ10 have been reported in plasma and the cerebellum of MSA-C patients, thus mutations in $C O Q 2$ and altered levels of COQ10 may be region- or subtype-specific and may not represent common genetic factors for MSA (Barca et al. 2016; Schottlaender et al. 2016). Decreased levels of COQ10 may contribute to MSA pathogenesis due to decreased electron transport in the mitochondria and increased vulnerability to oxidative stress (Nakamoto et al. 2018).

Duplications and triplications of the SNCA gene, which codes for aSyn, may cause familial PD with glial cytoplasmic inclusions in some members (Gwinn et al. 2011). An A53E SNCA mutation was reported in a Finnish patient displaying neuronal and glial aSyn pathology throughout the brain and spinal cord (Pasanen et al. 2014). Additionally, a G51D SNCA mutation was reported in a British pedigree with autosomal dominant juvenile Parkinsonism, which also displayed neuropathological hallmarks of MSA with GCIs but without the typical clinical features of MSA (Kiely et al. 2013, 2015). It is important to note that in PD, greater disease severity and duration leads to increased accumulation of aSyn in oligodendroglia, thus these point mutations may be causing a more aggressive form of PD and not pure MSA (Halliday et al. 2011; Katzeff et al. 2019). Two single-nucleotide polymorphisms of the SNCA locus have been identified in two separate studies (Al-Chalabi et al. 2009; Scholz et al. 2009), however these were not replicated in the largest MSA genome-wide association study (Sailer et al. 2016). This same study by Sailer and colleagues did, however, identify single-nucleotide polymorphisms in other genes, such as MAPT, FBX047, EL0VL7, and EDN1, which may have implications in MSA pathogenesis (Sailer et al. 2016). Other studies have proposed genetic variants for increased MSA susceptibility, such as GBA (Mitsui et al. 2015), SLC1A4, SQSTM1, and EIF4EBP1 (Soma et al. 2008), and LRRK2 (Heckman et al. 2014; Lee et al. 2018; Riboldi et al. 2019),
Some of these risk variants were also found in multiplex families where MSA coincided with PD and suggests some overlap in genetic risk between diseases (Mitsui et al. 2015).

No environmental factors have yet to be unequivocally linked to an increased risk of MSA. Initial case-controlled reports in North America and Europe showed an increased risk of developing MSA for those who worked in agriculture, had exposure to plastic monomers and additives, metals and organic solvents (Nee et al. 1991; Vanacore et al. 2005), however, these findings were unable to be replicated in follow-up studies (Cho et al. 2008; Vidal et al. 2008). As observed in PD, two studies have shown a protective effect of smoking in which individuals who smoke tobacco are less likely to get MSA than those who do not (Vanacore et al. 2000; Chrysostome et al. 2004). Interestingly, this protective effect of smoking is not seen in progressive supranuclear palsy, a tauopathy, which may indicate an interaction between smoking and aSyn.

Given the conflicting data surrounding the influence of genetics and the environmental impact on MSA, there is little scientific evidence to correlate these factors with an increased risk of MSA. A recent study identified intestinal inflammation in cases with inflammatory bowel disease as a potential risk factor of MSA using clinical data available from to the Danish National Patient Register (Villumsen et al. 2019). The overall incidence of MSA cases in this study was low which is typical of epidemiological. A definite diagnosis of MSA requires post-mortem evaluation, which is lacking in many of the epidemiological and genetic studies. Larger numbers of pathologically confirmed MSA cases and healthy controls are required in future studies to reach sufficient power (Vanacore 2005; Jellinger 2018).

\section{Neuropathology}

The precise mechanism by which degeneration occurs in MSA remains unclear. Converging evidence from postmortem and experimental studies suggests that MSA is a primary oligodendrogliopathy where disruptions in the oligo-myelin-axon complex lead to secondary neurodegeneration (Wenning et al. 2008; Jellinger 2015, 2018), rather than MSA being a primary neuronal disorder with secondary GCI accumulation of aSyn from a neuronal origin (Ubhi et al. 2011). However, the presence of aSyn mRNA within oligodendroglia remains controversial and is an important point that to this day requires clear resolution. Initial reports indicating the lack of aSyn mRNA in oligodendroglia have been challenged by recent studies demonstrating the presence of aSyn mRNA in oligodendrocytes from post-mortem MSA tissue (Miller et al. 2005; Jin et al. 2008; Asi et al. 2014). Developmental studies utilizing embryonic stem cells and induced pluripotent stem cells have shown aSyn protein and mRNA in oligodendrocyte precursor cells (OPCs) 
that diminishes as oligos mature (Djelloul et al. 2015), and experimentally induced expression of aSyn in OPCs hinders development of oligodendroglia and their ability to myelinate (Ettle et al. 2014; May et al. 2014). In related demyelinating disorders, sparse clusters of oligodendrocytes of the spinal cord and the cerebrum express aSyn (Falcao et al. 2018; Jakel et al. 2019). It has been speculated that an overlap between different demyelinating diseases, such as multiple sclerosis (MS) and MSA, might exist (Jellinger and Wenning 2016). Curiously, these aSyn-positive oligodendrocytes in MS cases were mainly found within active or chronic white matter lesions (Lu et al. 2009), suggesting that aSyn expression could be triggered, possibly transiently in demyelinating lesions.

These recent findings suggest that oligodendroglia can express aSyn and that they might be the primary source of aSyn found in MSA GCI's. However, this does not rule out other potential mechanisms such as passive transmembrane diffusion and endocytosis. The impact of the neuronal endosomal-lysosomal system in the processing of aSyn in PD is well established, while lysosomes contribute to the pathogenesis of MSA, enabling oligodendroglial and neuronal uptake of aSyn (Puska et al. 2018). Reduced oligodendrocyte-derived enriched microvesicles (OEMVs) could be an important mechanism related to pathological aSyn aggregation in oligodendrocytes (Yu et al. 2020) and more recently, aSyn was also isolated from both neuronal- and oligodendroglial-derived exosomes from the blood of MSA patients where it was found to be significantly elevated within these exosomes. Compared to PD exosomes, MSA exosomes contained significantly higher levels of aSyn making blood exosomes potentially useful for biomarkers of MSA (Dutta et al. 2021). In vitro and in vivo studies have experimentally demonstrated the transfer of aSyn from neurons to oligodendrocytes (Kisos et al. 2012; Rockenstein et al. 2012; Reyes et al. 2014; Kaji et al. 2018). Aggregated aSyn can act in a prion-like manner that propagates throughout the neuraxis in MSA (Watts et al. 2013; Peelaerts et al. 2015; Prusiner et al. 2015; Peng et al. 2018; Woerman et al. 2015, 2018, 2019). Supporting the notion that MSA is a primary oligodendrogliopathy, GCIs are first observed in regions where significant neuronal loss occurs and GCI density correlates with the degree of neuron loss (Papp and Lantos 1994; Ozawa et al. 2004; Yoshida 2007). Apart from aSyn pathology in oligodendrocytes, abnormal accumulation of fibrillary aSyn is also present in neuronal cytoplasm inclusions (NCIs) and neuronal nuclear inclusions (NNIs) as well as in neurites human MSA brains examined at post-mortem (Papp and Lantos 1994; Yoshida 2007). Indeed, postmortem studies of MSA brains have suggested that NNIs develop early in the disease process in the pontine nuclei and inferior olives (Nishie et al. 2004; Wakabayashi et al. 2005; Wakabayashi and Takahashi 2006). NCIs are widely distributed throughout the brain; however, their frequency does not seem to relate to the degree of neuron loss (Ozawa et al. 2004). Neuronal accumulation of aSyn and potential relevance to disease symptomatology and progression are described below in the section entitled "Atypical MSA". Furthermore, GCIs are the hallmark of MSA and are not seen as frequently in $\mathrm{PD}$, even though both diseases share similar lesion patterns in many overlapping circuits (Halliday 2015).

The accumulation of aSyn causes dysfunction in normal oligodendrocyte, leading to demyelination, axonal damage, reduced neurotrophic support, and subsequent neurodegeneration (Matsuo et al. 1998; Ubhi et al. 2010; Jellinger 2014). The immune system has been shown drive pathogenesis in MSA, as evidence from post-mortem and experimental studies have shown astrogliosis, microglial activation, and recently an infiltration of T cells (Stefanova et al. 2007; Rydbirk et al. 2017; Refolo et al. 2018; Williams et al. 2020). Severe neuron loss is seen in several brain regions, such as the putamen, substantia nigra, inferior olives, pons, and cerebellum. Despite the accumulation of aSyn in oligodendroglia, demyelination, and the proposed pathogenic role of GCIs, the number of oligodendrocytes in MSA brains seems to be preserved or only a modest reduction when compared to healthy controls (Nykjaer et al. 2017; Salvesen et al. 2017).

On the cellular level, oligodendroglial pathology in MSA results in accumulation of another protein, p25 $\alpha$, in oligodendrocytes from patients with MSA (Kovacs et al. 2004; Orosz et al. 2004). P25 $\alpha$, also known as tubulin polymerization-promoting protein (TPPP) (Takahashi et al. 1991), is an oligodendroglial-specific phosphoprotein functionally involved in myelination and stabilization of microtubules (Ovadi and Orosz 2009). Under physiological conditions, p25 $\alpha$ resides in the myelin sheath; however, in MSA patients, it is shifted into oligodendroglial cell bodies preceding aSyn aggregation (Song et al. 2007). Furthermore, p25 $\alpha$ stimulates aSyn aggregation in vitro (Lindersson et al. 2005), and up to $50 \%$ of oligodendroglia show abnormal accumulation of $\mathrm{p} 25 \alpha$, which is often co-localized with insoluble aggregates of aSyn in GCIs (Song et al. 2007; Wenning et al. 2008). Paralleling the relocation of $\mathrm{p} 25 \alpha$, a dramatic decrease of total levels of myelin basic protein (MBP) and concurrent increase in degraded MBP is observed. The coexpression of $\mathrm{p} 25 \alpha$ and aSyn in rat oligodendroglial cell line OLN-93 resulted in the formation of pS129+aSyn inclusions and showed a rapid retraction of microtubules from cellular processes followed by a protracted development of apoptosis (Kragh et al. 2009).

As mentioned previously, aSyn was discovered to be the main component of Lewy bodies in PD, and subsequently identified as a major protein aggregated in GCIs found in patients with MSA, thus linking the process of aggregation of aSyn to the pathogenesis of these diseases (Spillantini 
et al. 1998). aSyn found in GCIs undergoes a number of post-translational modifications, such as oxidative modifications, tyrosine nitration, and phosphorylation at serine 129 (Duda et al. 2000a, b; Giasson et al. 2000; Kahle et al. 2002; Beyer 2006; Beyer and Ariza 2007). Recent efforts have sought to investigate how the same protein, aSyn, can misfold and accumulate specifically in different cell types in the brain causing distinct diseases. The generation of pure fibrillar aSyn polymorphs with structural and phenotypic differences has led to the belief that different "species" or "strains" of aSyn may be responsible for the heterogeneity of synucleinopathies (Bousset et al. 2013). Supporting this hypothesis, distinct aSyn assemblies, "fibrils" and "ribbons", displayed vast differences in terms of aSyn pathology and spreading when injected into animals (Peelaerts et al. 2015). Moreover, aSyn extracted from brain samples of PD, DLB, and MSA subjects have shown distinct properties experimentally (Masuda-Suzukake et al. 2013; Watts et al. 2013; Recasens et al. 2014; Peng et al. 2018; Van der Perren et al. 2020). Experiments showing that oligodendrocytes, but not neurons, transform misfolded aSyn into a "GCI strain" have highlighted the importance of the intercellular milieu on generating distinct aSyn strains (Peng et al. 2018). Moreover, GCI-derived aSyn has been shown to be more potent in producing neurodegeneration, aSyn propagating pathology, and inflammation than both PD- and DLB-derived aSyn (Prusiner et al. 2015; Peng et al. 2018; Van der Perren et al. 2020).

The molecular origin of these aSyn MSA protein strains likely depend on the host cellular environment or the interactions between oligodendroglia and aSyn. Unique oligodendroglial factors that seed and interact with aSyn, such as the aforementioned $\mathrm{p} 25 \alpha$ protein can influence the folding landscape of aSyn (Peng et al. 2018; Ferreira et al. 2021). In vitro aggregation of aSyn with oligodendroglial extracts or p $25 \alpha$ results in the assembly of an aggressive aSyn strain that causes exacerbated neurotoxicity when injected in mouse brain (Ferreira et al. 2021). Cryo-EM studies have confirmed that MSA fibrils are unique, and that they are structurally distinct compared to fibrils isolated from the brain of people with PD or DLB. Within the core of the MSA fibril, there is a large cavity with protruding charged side chains that are covered by a non-proteinaceous residue. This density could be an important cofactor required for screening these charged residues and the assembly of the MSA strain (Schweighauser et al. 2020). Within different regions of MSA brain, slight variations within the fibril conformation are observed, further indicating that a cloud of related assemblies could exist for a given disease. While an exciting paradigm shift in understanding synucleinopathies, the strain differences need to be more closely examined and reproduced as in vitro amplification of prion-like proteins do not always recapitulate how they behave in vivo.

\section{Atypical MSA}

While MSA-P and MSA-C, in combination with autonomic dysfunction represent the typical MSA presentations, uncommon clinicopathologic forms of MSA exist, in which several subtypes do not fit the current classification (Watanabe et al. 2016). These forms of MSA include minimal change MSA, non-motor MSA and incidental MSA. All present with variable aSyn, glial or neuronal pathology.

The term "minimal change" MSA describes a pathological variant of MSA that is characterized by widespread and typical distribution of GCIs; however, neuronal loss is restricted to the substantia nigra and locus coeruleus (Wenning et al. 1994a, b). Ling and colleagues report that, of the six "minimal change" MSA cases evaluated, three presented with Parkinsonism and three presented with autonomic features (Ling et al. 2015). When compared to MSA controls, subjects with "minimal change" MSA were found to have widespread GCIs with a significant increase of NCIs in the caudate and SN. Moreover, cases of "minimal change" MSA had an earlier age of onset (Mean 38 vs 57.6), a more rapid clinical progression, and a shorter disease duration (mean 5.3 vs 8 years), suggestive of a more aggressive variant of MSA (Ling et al. 2015).

Additionally, Wakabayashi and colleagues reported a case of early "minimal change" MSA of the cerebellar variant. The authors report a 57-year-old-woman with a 15-month disease duration and neuronal loss restricted to olivopontocerebellar system. Despite widespread GCIs throughout the CNS, neuronal aSyn pathology was confined to the pontine and inferior olivary nuclei (Wakabayashi et al. 2005). The authors state that GCI formation is the earliest stage of the degenerative process, which causes destruction of myelin, together with neuronal aSyn accumulation, leading to secondary neuronal degeneration.

A second interesting and rare manifestation of MSA is described as non-motor MSA, which presents clinically with autonomic failure in the absence of motor signs or symptoms (Gaig et al. 2008; Riku et al. 2017). Gaig and colleagues report the case of a 60 -year-old man with a history of stridor, RBD and urogenital autonomic disturbances, but never progressed to the development of overt Parkinsonism or cerebellar signs. Neuropathological assessment revealed widespread aSyn-positive GCIs accompanied by severe neuronal loss and gliosis in the cerebellar, brainstem and spinal cord areas with only mild pathology in the putamen, $\mathrm{SN}$, and globus pallidus (Gaig et al. 2008). Riku et al. describe four patients identified as having non-motor MSA, in which symptoms presented as urinary disorders, and progressed to nocturnal stridor, anhidrosis, and orthostatic hypotension. Pathologically, marked neuronal loss and gliosis was observed in the intermediolateral column and Onuf's nucleus, as well as severe loss of serotonergic neurons in 
the ventrolateral medulla and the nucleus raphe obscurus, with abundant GCIs in the medullary reticular formation, which drastically differs from classical MSA cases (Riku et al. 2017). In these described reports of non-motor MSA, all subjects suffered from inspiratory stridor, depletion of medullary serotonergic neurons, and died of sudden death, and it has been postulated that the loss of serotonergic neurons could be responsible for the sudden death observed in MSA (Tada et al. 2009).

Aoki and colleagues describe another atypical MSA subtype, in which patients present clinically with frontotemporal dementia symptoms with the addition of widespread GCI pathology (Aoki et al. 2015). None of the patients displayed autonomic dysfunction; however, all had severe limbic and cortical aSyn pathology as both GCI and NCI formations. Neuronal inclusions were heterogeneous in nature but included aSyn positive Tau negative Pick body-like inclusions that strongly associated with neuronal loss in the hippocampus and amygdala.

Only in rare instances, GCIs are found in autopsy cases of neurologically normal individuals. However, there are reports of cases with GCI pathology in the SN accompanying neuronal loss but without demyelination (Fujishiro et al. 2008). The two cases reported by Fujishiro and colleagues were 82 and 96 years of age, and as such one may consider the observed GCI pathology an age-related phenomenon, classifying them as "preclinical/prodromal" or "incidental MSA".

\section{MSA Models}

One reason MSA remains an elusive and puzzling disease to study is the paucity of reliable animal models. This is due, in part, to the complexity of neuropathological features and a questionable genetic influence. Over the years, great effort has gone into the production of in vitro and in vivo MSA models, and recent technological advancements have allowed for the development of more accurate models.

Initially, in vitro modeling of MSA relied on aSyn expression in an astrocytoma cell line U373 (Stefanova et al. 2001, 2002; Stefanova et al. 2003a, b), primary mix rat glial cultures (Stefanova et al. 2002), primary oligodendroglial cell line OLN-93 (Kragh et al. 2009), and primary rodent oligodendroglial cell line CG4 (May et al. 2014; Valera et al. 2017). Using vectors to overexpress full-length human wildtype aSyn (1-140) or C-terminally truncated aSyn (1-111) in astrocytoma cell line U373 and mixed primary mixed glial cultures, Stefanova and colleagues demonstrated widespread fibrillar aSyn aggregates, which were more abundant in C-terminally truncated aSyn-expressing cells. aSyn overexpression in these cells caused neuronal death and increased susceptibility to oxidative stress. These observations were observed in both astrocytes and oligodendrocytes overexpressing aSyn (Stefanova et al. 2001, 2002; 2003a, b). To investigate the potential of microtubule stabilizing protein p $25 \alpha$ to stimulate aSyn aggregation, Kragh and colleagues co-expressed human p25 $\alpha$ and aSyn in the rat oligodendroglial cell line OLN-96. A rapid relocation of microtubules from the cellular processes to the perinuclear region was observed. This was followed by lasting apoptosis with caspase- 3 activation and nuclear chromatin condensation. This response was dependent on the phosphorylation of aSyn at serine 129 , and the co-expression of $\mathrm{p} 25 \alpha$ and aSyn was required, as neither protein alone elicited these toxic effects (Kragh et al. 2009). Subsequent studies showed that the overexpression of p25 $\alpha$ or aSyn accelerated the recruitment of endogenous aSyn following the addition of aSyn preformed fibrils (PFFs) (Mavroeidi et al. 2019). These studies highlight the role of $\mathrm{p} 25 \alpha$ in the formation of pathological aSyn species in oligodendroglia and the corresponding pathology in MSA.

May and colleagues used the GC4 oligodendroglial cell line and demonstrated that overexpression of aSyn impairs the maturation of oligodendrocyte progenitor cells (OPCs). Cells expressing aSyn displayed abnormal branching, reduced intracellular MBP, and the inability to properly form myelin sheaths (May et al. 2014). These results may provide insight into the progression of MSA, as dysfunctional aSyn expressing OPCs could be unable to remyelinate damaged areas in the MSA brain.

While these initial in vitro studies have provided valuable insight into mechanistic components of the disease process, the use of cell lines have clear limitations. Various genetic modifications have been performed to immortalize cell lines and drive continuous growth. As such, it may be difficult to distinguish artifact from disease-specific pathology and findings must be validated in other models.

\section{Stem cell based models of MSA}

The advent of cellular reprograming of fibroblasts into induced pluripotent stem cells (iPSCs) has allowed for the study of human neural tissue, and more importantly, patientderived neural tissue (Takahashi et al. 2007). Utilizing this technology, Djelloul and colleagues successfully reprogramed fibroblasts from patients with MSA, PD, and control subjects into functional oligodendrocytes. By recapitulating human development in a dish, they observed the presence of SNCA transcripts and aSyn protein in oligodendrocyte progenitors, which decreased after maturation into oligodendrocytes (Djelloul et al. 2015). Notably, the transient expression of aSyn was observed in cells derived from MSA and control subjects; however, it does confirm the presence of aSyn mRNA in oligodendrocytes and provides the potential hypothesis that aberrant re-expression of SNCA could be 
triggered during disease state and provide the source of oligodendroglial aSyn in MSA.

iPSC-derived neurons from MSA and control subjects have been differentiated into dopaminergic and cortical neurons to further investigate mitochondrial function in MSA (Monzio Compagnoni et al. 2018; Nakamoto et al. 2018). To look more closely at the implications of COQ2 mutations on mitochondrial function, Nakamoto and colleagues reprogrammed peripheral blood mononuclear cells from patient with a compound heterozygous COQ2 mutation, an idiopathic MSA patient, and three control lines of diverse descent (Caucasian, African, and Japanese origin). COQ2-mutated MSA derived neurons displayed a significant reduction in the mean area of the inner mitochondrial membrane, as well as reductions in COQ10 and vitamin $E$ levels, and changes in mitochondrial respiratory chain activity, compared to sporadic MSA and control derived neurons (Nakamoto et al. 2018). Monzio Compagnoni and colleagues examined mitochondrial and autophagic dysfunction in iPSC-derived dopamine neurons from MSA patients and healthy controls. This study also found dysregulation involving respiratory chain activity, mitochondrial content, and COQ10 biosynthesis in MSA patient-derived neurons. Additionally, treatment with bafilomycin A, which inhibits the fusion of the autophagosome and the lysosome, yielded increased basal levels of LC3-II in MSA samples indicating impairment in autophagic flux (Monzio Compagnoni et al. 2018). The authors hypothesized a vicious cycle in which mitochondrial dysfunction could be triggered by inadequate autophagy, resulting in impaired mitophagy and the accumulation of dysfunctional mitochondria and further dysregulation of autophagy.

While cell-based models of MSA offer the ability to study the disease in human/patient-derived cells, the fact that MSA affects multiple cell lineages and the difficulty to recapitulate the complex network of the CNS causes limitations to elucidate the progression of pathology and adequately assess the efficacy of novel therapeutics.

\section{Toxin based in vivo models of MSA}

Neurotoxin-based animal models of MSA were initially developed to reproduce the anatomical lesion of striatonigral degeneration underlying the L-DOPA unresponsive Parkinsonism observed in MSA. This effort combined previously established neurotoxin lesion paradigms used to model PD and Huntington's disease, using 6-hydroxydopamine (6-OHDA) and quinolic acid (QA) to selectively target nigral dopamine neurons and striatal GABAergic medium spiny neurons, respectively. The initial "double toxin-double lesion" model was established by a unilateral injection of 6-OHDA in the median forebrain bundle (MFB) followed by QA in the striatum, which induced a near complete loss of nigral DAergic neurons and a dose-dependent excitotoxic loss of striatal medium spiny neurons. Behaviorally, this model exhibited classical ipsilateral amphetamine induced rotations, which were abolished by fetal allografts (Wenning et al. 1996). A subsequent study investigated the effects of lesion sequence (nigrostriatal degeneration vs striatonigral degeneration) and found that while prior striatal lesioning with QA did not affect 6-OHDA-induced nigral degeneration, initial striatal DAergic denervation from 6-OHDA lesions was found to decrease the neurotoxic effects of QA. A bilateral deficit in the stepping test, as well as an absent levodopa response, was also observed in this double-toxin model (Scherfler et al. 2000; Stefanova et al. 2004; Kollensperger et al. 2007). Ghorayeb and colleagues modified the "double toxin-double lesion" approach to model earlystage MSA-P using simultaneous low-dose QA and 6-OHDA in the lateral striatum. This strategy resulted in exacerbation of QA-induced striatal degeneration, with a slight reduction in nigral neuron degeneration. Behaviorally, deficits in the stepping test were observed and rotational asymmetry was abolished, indicating a dopamine unresponsive phenotype (Ghorayeb et al. 2001).

In an effort to prevent interactions between both sites of degeneration, a "single toxin-double lesion" approach was developed in rats using either 3-nitropropionic acid (3-NP), a succinate dehydrogenase inhibitor, or 1-methyl4-phenylpyridinium ion $\left(\mathrm{MPP}^{+}\right)$, a mitochondrial complex I inhibitor. Either neurotoxin induces combined degeneration of both striatal and nigral neurons when injected into the striatum, as well as bilateral behavioral deficits (Waldner et al. 2001; Ghorayeb et al. 2002a, b).

Systemic administration of neurotoxins avoids intracerebral injections and produces a progressive neurodegeneration, which can mimic the temporal dimension of the human disease. Different injection paradigms were utilized to explore if the order of neurotoxin administration had any effect on degeneration, which was observed in the "dualtoxin dual-lesion" intracerebral approach. In all administration paradigms, intraperitoneal injection of 1-methyl-4phenyl-1,2,3,6-tetrahydropyridine (MPTP) and 3-NP in mice resulted in the development of bilateral SND (Stefanova et al. 2003a, b; Fernagut et al. 2004). As in the intracerebral dual toxin models, prior administration of MPTP reduced the vulnerability of striatal neurons to $3-\mathrm{NP}$, and administration of 3-NP first reduced the vulnerability of nigral dopaminergic neurons to MPTP. Locomotor deficits were more pronounced with the initial administration of 3-NP, which correlated with the loss of striatal neurons (Stefanova et al. 2003a, b). Unlike the sequential administration of MPTP and 3-NP, the combined systemic administration of these neurotoxins resulted in a more pronounced neurodegeneration than either toxin alone, and elicited decreased motor performance, altered gait patterns, and impaired balance 
(Fernagut et al. 2004). This systemic approach was also utilized in nonhuman primates, whereby chronic administration of 3-NP induced a progressive aggravation of parkinsonian motor features in MPTP-treated monkeys, which did not respond to levodopa administration. 3-NP treatment induced hindlimb dystonia that correlated to bilateral striatal degeneration visualized by in vivo MRI (Ghorayeb et al. 2000; Ghorayeb et al. 2002a, b). Intracerebral and systemic toxinbased models were able to reproduce levodopa-unresponsive striatonigral degeneration that is observed in MSA. However, these models were unable to recapitulate any aspect of aSyn + GCI formation or oligodendroglial dysfunction, which are key pathological hallmarks of MSA and important disease features as growing evidence points to MSA being a primary oligodendrogliopathy (Wenning et al. 2008) and for the most part have been discarded.

\section{Transgenic in vivo models of MSA}

To address the concerns that arose regarding neurotoxinbased models of MSA, several transgenic ( $\mathrm{tg}$ ) mouse models have been developed, in which human wild-type aSyn was expressed specifically in oligodendrocytes using different oligodendroglial-specific promoters. Targeted aSyn expression was achieved using the proteolipid (PLP) promoter (Kahle et al. 2002), the myelin basic protein (MBP) promoter (Shults et al. 2005) or the 2',3'-cyclic nucleotide 3'-phosphodiesterase (CNP) promoter (Yazawa et al. 2005). All three tg lines recapitulate the oligodendroglial accumulation of insoluble alpha-synuclein.

When expression of $\alpha$ Syn was driven by the PLP promoter (PLP-aSyn), hyperphosphorylated aSyn at serine 129 (pSer129) was observed in GCIs. (Kahle et al. 2002). Initial studies using this model did not observe neuronal loss or motor impairments in mice up to 10 months of age; however, subsequent studies found early microglial activation and mild degeneration of nigral dopamine neurons that corresponded to a subtle motor phenotype of reduced hind limb strength. Despite the formation of GCIs, oligodendroglial dysfunction was not observed, supported by the lack of demyelination or oligodendrocyte loss (Stefanova et al. 2005, 2007; Fernagut et al. 2014). Many non-motor and features of dysautonomia have been observed in the PLP- $\alpha$ Syn mouse, such as heart rate variability, impaired respiratory control, bladder dysfunction, REM sleep behavior disorder, (Stefanova et al. 2005; Stemberger et al. 2010; Boudes et al. 2013; Kuzdas et al. 2013; Fernagut et al. 2014; Flabeau et al. 2014; Hartner et al. 2016). Exposure of mitochondrial toxin 3-NP or systemic proteasome inhibition in the PLP-aSyn mouse exacerbated the MSA phenotype and resulted in neuronal loss in the striatum, substantia nigra, inferior olives, pontine nuclei, and cerebellar cortex (Stefanova et al. 2005, 2012). Environmental triggers that induce oxidative stress protein degradation deficits may induce or play a synergistic role in driving the pathology in MSA.

Several tg mouse lines were created using the MBP promoter to overexpress aSyn at varying degrees (MBPaSyn) (Shults et al. 2005). Fibrillar perinuclear inclusions were formed that were ubiquinated and phosphorylated at Ser129. The most abundant formation of GCI pathology was observed in white matter tracts, the striatum, brainstem, and cerebellum, which corresponded to demyelination and astrogliosis observed throughout white matter tracts, loss of nigral dopamine neurons, reduced striatal $\mathrm{TH}+$ fiber density, and loss of striatal neurons. Ultrastructural examination of oligodendrocytes revealed prominent mitochondrial abnormalities, such as enlarged and irregularly shaped organelles, as well as loss of glial cell line-derived neurotrophic (GDNF) (Shults et al. 2005; Ubhi et al. 2010). The decreased levels of GDNF highlight oligodendrocyte dysfunction and point to a mechanism by which oligodendroglial pathology can cause degeneration in neurons. Importantly, GCI burden and subsequent neurodegeneration was dependent on the levels of aSyn expression. The severity of motor phenotype also varied greatly across the different MBP-aSyn lines, with severe tremor, ataxia, seizures and premature death in the highest expressing line (high expressor line 29, MBP29) to mild tremor and variable motor impairment in intermediate and lower expressing lines (Shults et al. 2005). Results from these studies suggest that the level of aSyn expression dictate the degree of neurodegeneration in MSA.

Recently, Mészáros and colleagues investigated line 29 the MBP-aSyn mouse to assess if the overexpression of aSyn under the MBP promoter recapitulates features of the MSA-C variant (Meszaros et al. 2021). Similar to the disease in humans, this model shows GCI formation within cerebellar white matter accompanied by a severe myelin deficit. A significant reduction in MBP and PLP shown by Western Blot was observed at 8 weeks, as well as reductions in myelin lipid content in the pyramidal tract as well as the superior, middle, and inferior cerebellar peduncles. An increase of Olig2 + oligodendrocytes was observed in the cerebellar white matter, while the proportion of PDGFR $\alpha+$ oligodendrocyte precursor cells was slightly decreased (Meszaros et al. 2021). In line with previous studies, these results point to an aSyn mediated dysfunction of oligodendroglia leading to the demyelination observed in MSA, rather than an overt loss of oligodendrocytes (Ettle et al. 2014; May et al. 2014). Accompanying the loss of myelin was an early and sustained increase of IBA $1+$ cells in the cerebellar white matter beginning at 8 weeks of age in the MBP-aSyn mice, with an $18 \%$ loss of Purkinje cells in the cerebellar cortex by 16 weeks. As a consequence of the combined olivopontocerebellar atrophy observed in these mice, gait analyses revealed decreased walking speed, increased stride length and width between hind paws, and less dual diagonal support—akin 
to the wide-based and unsteady gait often observed in MSA-C patients. Taken together, this model shows features of MSA-C in respect to both pathological findings, as well as a behavioral phenotype that is akin to cerebellar ataxia.

Expression of $\alpha$ Syn under the CNP promoter (CNP-aSyn) resulted in the formation of GCI-like inclusions and neurodegeneration most prominently in the cerebral cortex and spinal cord (Yazawa et al. 2005). CNP-aSyn mice developed an age-related progressive reduction of rotarod performance compared to control mice. Ultrastructural examination of oligodendrocytes from these mice displayed degraded myelin, extensive accumulation of lysosomes, and cytoplasmic myelin fragments, suggesting autophagocytosis. While neuronal cell bodies did not stain positive for human aSyn, positive staining was observed in neurons using antibodies specific for mouse aSyn, indicating the accumulation of endogenous aSyn in neurons of CNP-aSyn mice.

Tg MSA mice have continuous expression of aSyn in oligos, which has been shown to alter oligodendroglial maturation (Ettle et al. 2014; May et al. 2014). As such, forced expression of aSyn throughout development could result in disrupted brain circuitry, and thus deficits observed in these tg models may not entirely represent the disease course in MSA. Recently, Tanji and colleagues developed an adult-onset aSyn overexpression model of MSA using a Cre-loxP system in mice to induce aSyn expression in oligodendroglia at chosen time (Tanji et al. 2019). To generate this model, mice containing a chicken $\beta$-actin gene and a promoter (CAG promoter) followed by a loxP-flanked (flox) stop cassette-controlled aSyn gene were mated with mice that contained the Cre/estrogen receptor (ER) specifically expressed under the PLP promoter. As such, injection of tamoxifen induced overexpression of aSyn specifically in oligodendrocytes that was phosphorylated at Ser129 and resistant to proteinase $\mathrm{K}$ digestion. aSyn expression gradually spread throughout the CNS, mainly in white matter of the brainstem and cerebellum, but also in grey and white matter of the spinal cord. As GCI formation, neuronal cytoplasmic and neuronal nuclear inclusions were observed in the putamen and brainstem. Interestingly, $30 \%$ of the male mice exhibited sudden death following tamoxifen injection. Beginning 50 weeks following tamoxifen injection, behavioral abnormalities began to appear, as well as increased Iba1 and GFAP staining intensity. No neuronal loss was observed, however KB staining showed relatively weaker myelin staining in the spinal cord (Tanji et al. 2019). The tamoxifen inducible MSA mouse avoids the pitfall of sustained aSyn observed in tg MSA mice by inducing expression in adult mice, however, the GCIs formed in both the tg and inducible MSA mice are not specific to those regions affected in MSA. Both the tg MSA mice and the inducible adult-onset MSA mice overexpress in all oligodendroglia throughout the CNS, not just those regions affected by MSA.

\section{Viral vector-mediated models}

To allow for temporal control and region-specific overexpression of aSyn, our group and others have turned to AAVs to model MSA in rodents and NHPs. Bassil and colleagues utilized AAV1/2 to overexpress aSyn or GFP specifically in oligodendrocytes under the MBP promoter (Bassil et al. 2017). Targeting expression to the striatum, 80\% oligodendrocyte-specific transduction was observed in rats, which dropped to $\sim 60 \%$ in rhesus macaques. Prominent aSyn accumulation was observed, which was pS129+and resistant to proteinase K digestion. Progressive L-dopa unresponsive behavioral deficits was reported in rats overexpressing aSyn, which was accompanied by neurodegeneration beginning at 3 months and progressing at 6 months post-injection, with a $23 \%$ loss of NeuN + neurons in the striatum and a $66 \%$ loss of $\mathrm{TH}+$ nigral neurons (Bassil et al. 2017).

By taking advantage of AAV engineering techniques such as capsid shuffling and directed evolution, our colleagues were able to design an AAV capsid which displayed specific tropism towards oligodendroglia and this vector was called Olig001 In vitro binding assays showed that Olig001 transduced oligodendroglia 9 times more than AAV8 serotype in mixed cell cultures (Powell et al. 2016). Following striatal injection of Olig001 expressing aSyn or GFP under the constitutive CBh promoter, we found $>95 \%$ oligodendroglial-specific tropism in rats and $90-94 \%$ in rhesus macaques (Mandel et al. 2017). In rats, neurodegeneration corresponded with aSyn expression levels, where greater levels of demyelination and neuronal loss in both the striatum and SN were observed when using a tenfold higher titer of Olig001 (Marmion et al. 2021). In both species, widespread aSyn-rich GCIs were present, in which aSyn was phosphorylated at serine 129 and tyrosine 39 . These aggregates were resistant to proteinase $\mathrm{K}$, and were Thioflavin $\mathrm{S}$ positive, demonstrating the formation of GCIs similar to those observed in MSA. Titer-dependent degeneration was observed with a $14.7 \%$ loss of striatal $\mathrm{NeuN}+$ neurons and $21.7 \%$ loss of $\mathrm{TH}+$ nigral neurons in low-titer Olig001-aSyn injected rats $\left(2.4 \times 10^{11} \mathrm{vg} / \mathrm{ml}\right)$, which increased to a $23.8 \%$ and $35.9 \%$ loss of neurons in the striatum and SN of high-titer Olig001-aSyn injected rats $\left(3.2 \times 10^{12} \mathrm{vg} / \mathrm{ml}\right)$, respectively (Marmion et al. 2021). Progressive degeneration was observed in the Olig001aSyn NHP model of MSA, with demyelination observed but no cell loss after 3 months (Mandel et al. 2017). However, there was a $\sim 44 \%$ loss of $\mathrm{NeuN}+$ neurons in the putamen and a $11 \%$ loss of $\mathrm{TH}+$ nigral neurons was reported 6 months following injection of Olig001-aSyn, recapitulating the progressive nature of MSA. Robust increases in neuroinflammatory markers, such as HLADR, GFAP, and CD3, were observed in aSyn expressing monkeys (Marmion et al. 2021). 
To assess the immune response, we injected the Olig001 vector expressing either GFP or aSyn into the striatum of mice (Williams et al. 2020). Using both histology and flow cytometry, we observed a marked increase of MHCII expression on microglia, as well as an infiltration of pro-inflammatory monocytes into the CNS of animals injected with Olig001-aSyn, which was not observed in GFP injected controls. We also observed robust infiltration of CD4 and CD8 $+\mathrm{T}$ cells into the CNS and antigenexperienced CD4 and CD8 $+\mathrm{T}$ cells in the draining cervical lymph nodes following oligodendroglial expression of aSyn. Cytokine analyses revealed a significant increase in all Th1, 2, 17, and Treg associated cytokines IFN- $\gamma$, IL-4, IL-17a, and IL-10, respectively. To investigate the protective effect of reducing T cells, Tcrb ${ }^{-/-}$(CD4 and CD8 $\mathrm{T}$ cell knockout), or $C d 4^{-/-}$(CD4 T cell knockout) mice were injected with Olig001-aSyn and the CNS myeloid response was measured using histology and flow cytometry 4 weeks post-transduction. $\mathrm{Tcrb}^{-/-}$and $\mathrm{Cd}^{-/-} \mathrm{Olig} 001-$ SYN treated mice displayed a robust decrease in MHCII expression in both microglia and monocytes. Furthermore, $\mathrm{Tcrb}^{-/-}$and $\mathrm{Cd4^{-/- }}$ mice injected with Olig001aSyn showed reduced neurodegeneration, as no loss of myelin was observed in these mice compared to WT mice (Williams et al. 2020). Histological analysis of post-mortem brain tissue from MSA patients revealed significant increases of HLA-DR + microglia, CD3 +, CD4 +, and $\mathrm{CD} 8+\mathrm{T}$ cells in the putamen and $\mathrm{SN}$ compared to control subjects, confirming our findings from the Olig001 model (Williams et al. 2020). These results suggest that T-cell priming and infiltration into the CNS are key mechanisms of disease pathogenesis in MSA, and therapeutics targeting $\mathrm{T}$ cells may be disease modifying.

The use of viral vector technology also allows systemic targeting approaches for experimental or therapeutic purposes. We tested different rAAV viral vector serotypes, including rAAV2/7, rAAV2/8 and rAAV2/9, with different oligodendroglial specific promoters (Peelaerts et al. 2021). By combining rAAV2/9 with the myelin-associated glycoprotein (MAG) promoter expression specificity reached over 95\% in oligodendrocytes and it was possible to inject into the lateral ventricles and achieve widespread distribution of the viral vector in mouse CNS. Transgene expression was detected specifically in oligodendrocytes of the white matter spinocerebellar and spino-olivary tracts and the midbrain, including the pons and the cerebellar peduncles, which are areas that are typically affected in MSA. Future experiments will determine of such a model could be used for MSA modelling after injection of viral vector or in combination with seeding of MSA-specific fibrils.

\section{Fibrilar seeding models of MSA}

Finally, a model of MSA has been created via injecting aggregated aSyn fibrils directly into rodent brain. Because of the prion features of aggregated aSyn, fragmented aSyn fibrils can amplify and template in a strain-dependent manner and propagate pathology in vivo (Brundin and Melki 2017). Although the seeding capacities of fibrillar aggregates of aSyn have been useful for the development several PD models (Chung et al. 2019), it has been surprisingly difficult to establish seeding models that recapitulate features of MSA. Some studies have reported glial pathology in rodent brain, with inclusion formation in oligodendrocytes after injection of aSyn fibril injection (Peelaerts et al. 2015; Peng et al. 2018; Uemura et al. 2019). However, injection of MSA-derived fibrils or MSA strains, from patient brain into wild type, transgenic or viral vector models causes aggressive pathology with neuronal inclusions, neuroinflammation and motor behavioral deficits but without the typical MSAlike features such as GCIs, demyelination and brain atrophy (Peng et al. 2018; Holec and Woerman 2020; Van der Perren et al. 2020). The reasons for this are not fully understood, but a possible hypothesis is that an incomplete cellular environment in these models does not allow the propagation of MSA-like pathology. Peng and colleagues injected oligodendroglia-derived seeded fibrils in transgenic mice expression aSyn in oligodendrocytes where they observed progressive oligodendrogliopathy (Peng et al. 2018). Similarly, injection of aSyn ribbons or fibrils into MSA transgenic mice resulted in a significant behavioral changes, brain atrophy with demyelination and neuronal loss but also distinct MSAlike phenotypes (Torre Murazabal et al. 2020). It therefore seems that an interaction between host environment and aSyn assemblies dictate the conformational nature and the structural variation of a complex phenotype in MSA. Future studies will have to determine how reliable seeding models could be established, which will provide further insights into the mechanisms of disease progression in MSA.

\section{Conclusion}

The sequence of events that initiates and drives the pathogenesis of MSA is currently not fully understood. While post-mortem tissue from MSA patients provide a snapshot of end-stage disease, recent developments with cell and animal models of MSA (detailed in Table 1, Fig. 1) have better recapitulated critical aspects of the human pathology and molecular dynamics underlying the degenerative process, which have provided some insight into our understanding of the pathogenesis of MSA. The relocation of p25 $\alpha$ from the myelin sheath to the soma of oligodendroglia to form GCIs seems to precede and initiate 
Table 1 Overview of animal models of multiple system atrophy with key phenotypes

\begin{tabular}{|c|c|c|c|c|c|c|c|c|c|}
\hline \multirow[t]{2}{*}{ Model class } & \multirow{2}{*}{$\begin{array}{l}\text { Model } \\
\text { Type }\end{array}$} & \multirow{2}{*}{$\begin{array}{l}\text { Behavioral } \\
\text { deficits }\end{array}$} & \multirow{2}{*}{$\begin{array}{l}\text { Oligodendro- } \\
\text { glial dysfunc- } \\
\text { tion } \\
\text { (demyelina- } \\
\text { tion) }\end{array}$} & \multicolumn{3}{|c|}{ Neuronal loss } & \multirow{2}{*}{$\begin{array}{l}\text { Gliosis and } \\
\text { inflammation }\end{array}$} & \multirow{2}{*}{$\begin{array}{l}\text { Synuclein } \\
\text { pathology }\end{array}$} & \multirow[t]{2}{*}{ References } \\
\hline & & & & SND & OPCA & $\mathrm{SC}$ & & & \\
\hline \multirow[t]{8}{*}{ Toxin } & 6-OHDA and QA & +++ & - & +++ & - & - & $++($ GFAP $)$ & NA & $\begin{array}{l}\text { Wenning et al } \\
\text { (1996) }\end{array}$ \\
\hline & 6-OHDA and QA & +++ & - & +++ & - & - & $++($ GFAP $)$ & NA & $\begin{array}{l}\text { Scherfler et al. } \\
\text { (2000), }\end{array}$ \\
\hline & 6-OHDA and QA & +++ & - & +++ & - & - & NA & NA & $\begin{array}{l}\text { Stefanova et al. } \\
\text { (2004) }\end{array}$ \\
\hline & 6-OHDA and QA & +++ & - & +++ & - & - & NA & NA & $\begin{array}{r}\text { Kollensperger } \\
\text { et al. }(2007)\end{array}$ \\
\hline & 6-OHDA and QA & +++ & - & +++ & - & - & $++(\mathrm{GFAP})$ & NA & $\begin{array}{l}\text { Ghorayeb et al. } \\
\text { (2001) }\end{array}$ \\
\hline & 3NP, MPTP & +++ & - & +++ & - & - & $++($ GFAP $)$ & NA & $\begin{array}{l}\text { Ghorayeb et al. } \\
(2002 a, b)\end{array}$ \\
\hline & 3NP, MPTP & +++ & - & +++ & - & - & $++($ GFAP $)$ & NA & $\begin{array}{l}\text { Stefanova et al. } \\
(2003 \mathrm{a}, \mathrm{b})\end{array}$ \\
\hline & $\begin{array}{l}\text { 3NP, MPTP } \\
\text { (non-human } \\
\text { primates) }\end{array}$ & +++ & - & +++ & - & - & NA & NA & $\begin{array}{l}\text { Ghorayeb et al. } \\
(2002 a, b)\end{array}$ \\
\hline \multirow[t]{4}{*}{ Transgenic } & PLP-aSyn & $\begin{array}{l}+ \text { (dysautono- } \\
\text { mia) }\end{array}$ & - & + & $+*$ & + & + & ++ & Kahle et al. (2002) \\
\hline & MBP-aSyn & + & $++(\downarrow$ GDNF $)$ & ++ & + & NA & + & ++ & Shults et al. 2005 \\
\hline & CNPase-aSyn & + & + & ++ & NA & + & + & ++ & $\begin{array}{l}\text { Yazawa et al. } \\
\text { (2005) }\end{array}$ \\
\hline & $\begin{array}{l}\text { CAG-loxP-aSyn- } \\
\text { loxP x PLP-Cre }\end{array}$ & + & - & - & - & - & + & ++ & Tanji et al. (2019) \\
\hline \multirow[t]{3}{*}{ Viral vector } & $\begin{array}{l}\text { rAAV2/1 MBP- } \\
\text { aSyn } \\
\text { (rat and non- } \\
\quad \text { human primate) }\end{array}$ & $\begin{array}{l}++ \\
\text { (1-dopa unrespon- } \\
\text { sive) }\end{array}$ & NA & + & NA & NA & NA & ++ & Bassil et al. 2017 \\
\hline & $\begin{array}{l}\text { Olig001-CBh- } \\
\text { aSyn } \\
\text { (rat and non- } \\
\text { human primate) }\end{array}$ & - & + & - & NA & NA & ++ & ++ & $\begin{array}{l}\text { Mandel et al. } \\
\text { (2017) }\end{array}$ \\
\hline & $\begin{array}{l}\text { Olig001-CBh- } \\
\text { aSyn } \\
\text { (rat and non- } \\
\text { human primate) }\end{array}$ & - & + & + & NA & NA & $\begin{array}{l}+++(\text { GFAP } \\
\text { T-Cells })\end{array}$ & ++ & $\begin{array}{l}\text { Marmion et al. } \\
\text { (2021) }\end{array}$ \\
\hline
\end{tabular}

$N A$ Not assessed, - no effect, + weak effect, ++ moderate effect, +++ strong effect, * additional hit with neurotoxin.. 6-OHDA: 6-hydroxydopamine, $Q A$ quinolic acid, $3 N P$ 3-nitropropionic acid, $M P T P$ 1-methyl-4-phenylpyridinium ion, $C A G$ CMV enhancer, chicken beta-actin, $P L P$ proteolipid protein, $M B P$ myelin basic protein, CNPase 2', 3'-cyclic-nucleotide 3'phosphodiesterase

the aggregation of aSyn assemblies. The source of aSyn in MSA is unclear- as either aberrant expression of aSyn in oligodendroglia or the uptake of secreted aSyn from neurons may occur in MSA to form GCIs. Regardless, the formation of proteinaceous GCIs leads to a number of secondary events involving the dysfunction of oligodendrocytes, such as the disruption of myelin homeostasis, reduced trophic support to axons and neurons, and increased neuroinflammation. As such, MSA is currently viewed as a primary synucleinopathy with disruptions in the oligo-myelin-axon-neuron complex and secondary neurodegeneration (Wenning et al. 2008).

To date, there are no causative or disease-modifying therapies available for MSA, and symptomatic treatments are limited. Initial responsiveness to levodopa has been reported to be beneficial in $83 \%$ of MSA-P patients (Kollensperger et al. 2010), which declines to $31 \%$ effectiveness after a period of 3.5 years (Wenning et al. 2013). In fact, the diminishing effectiveness of 1-dopa often assists in the diagnosis of MSA. Other symptomatic treatment relies on the 
A

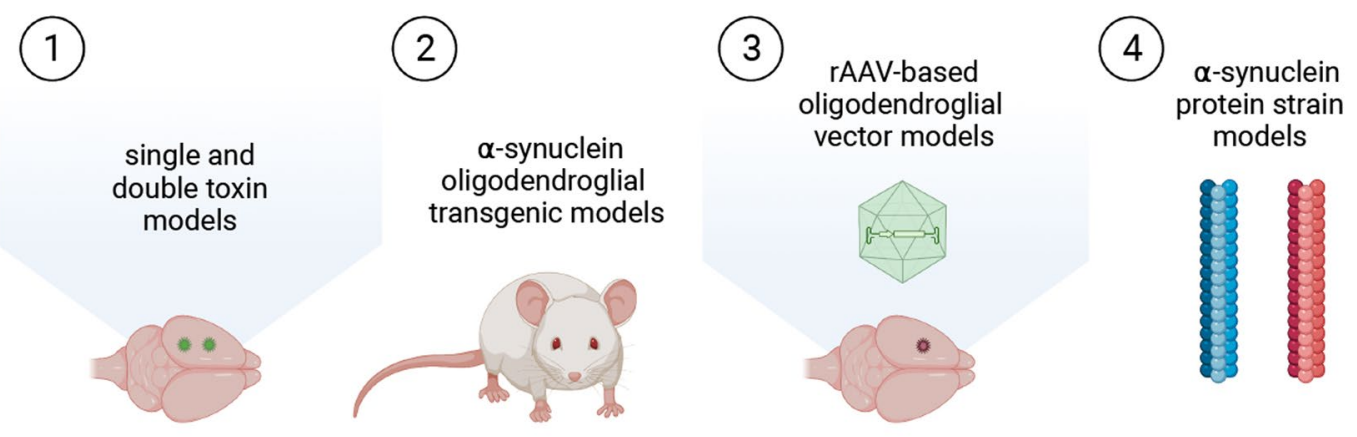

B

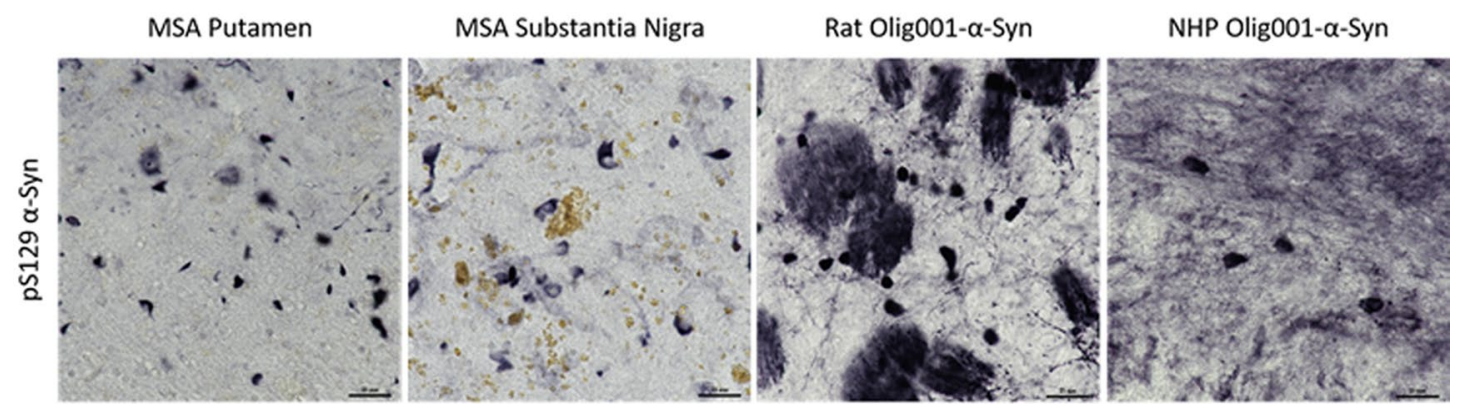

Fig. 1 Summary of animal models of MSA and recapitulation of MSA pathology. Animals have been utilized to model MSA in vivo using different approaches, such as 1 . Toxin based models in rodents and NHPs, 2. Transgenic mouse models overexpressing aSyn in oligodendroglial-specific promoters, 3. Virial vector-mediated aSyn overexpression models in rodents and NHPs, 4. aSyn protein strain

use of midodrine and droxidopa for orthostatic hypotension, anticholinergic agents for urinary tract dysfunction, laxative therapy for constipation, continuous positive air pressure and tracheotomy for breathing disorders, and botulinum toxin injections for dystonia (Perez-Lloret et al. 2015). A number of potential disease-modifying therapies for MSA are currently being tested in animal models of the disease ((HerasGarvin and Stefanova 2020).

Currently, there are four clinical trials underway targeting aSyn in MSA (https://clinicaltrials.gov/ct2/show/NCT04 165486, https://clinicaltrials.gov/ct2/show/NCT02270489, https://clinicaltrials.gov/ct2/show/NCT03100149), as well as 1 clinical trial examining the effects of GDNF gene delivery (https://clinicaltrials.gov/ct2/show/NCT04680065) in this population. In the realm of aSyn degradation enhancers, a phase II, double-blind, futility trial is being conducted with Rapamycin to target aSyn clearance in MSA patients (Palma et al. 2019). Results from a phase I study suggest good immunogenicity, safety and tolerability for active immunization using two vaccines, PD01A and PD03 targeting aSyn aggregation in MSA patients (Meissner et al. 2020). Two trials are underway targeting aSyn aggregation. Anle138b, an models (A). Pathological phosphorylation of aSyn at Serine residue 129 is observed in post-mortem MSA tissue in both the putamen and $\mathrm{SN}$, which is recapitulated in the striatum of rats and nonhuman primates injected with oligodendroglial-specific AAV capsid Olig001aSyn $(\mathbf{B})$. Scale bars $=25 \mu \mathrm{m}$

oral small compound targeting aSyn aggregation, has shown promise in PLP-aSyn MSA mice and a phase I trial in MSA patients has recently been announced (Heras-Garvin et al. 2019) https://www.modag.net/images/pressrelease_modag_ series_a.pdf). Additionally, a phase I trial with healthy volunteers is currently ongoing with small molecule iron chaperone PBT434, targeting iron-mediated aSyn accumulation, where preliminary results showed proportional pharmacokinetics up to $300 \mathrm{mg}$ and good tolerance (Stamler et al. 2019). Targeting neuroinflammation, a phase IIa trial in MSA patients with myeloperoxidase inhibitor Verdiperstat has shown improvement on clinical scores and reduced neuroinflammation by PET imaging (NCT02388295). A phase III study with Verdiperstat in MSA is planned (https://clini caltrials.gov/ct2/show/NCT04616456). Intrathecal administration of autologous mesenchymal stem cells has shown neuroprotective and immunomodulatory effects in animal models (Park et al. 2011; Stemberger et al. 2011). Studies in MSA patients have shown improvement on clinical scores and the safety profile examined through phase I/II study (Lee et al. 2008, 2012; Singer et al. 2019). However, a large, randomized, placebo-controlled study will be necessary 
before this approach is translated into the clinic. Based on the previously discussed findings on disruptions of CoQ10 levels in Asian patients with MSA-C, supplementation with CoQ10 is currently being investigated in a randomized, double-blind, placebo-controlled, multicenter phase II trial (UMIN000031771).

In summary, several factors seem to be associated with the pathogenesis of MSA and are potential therapeutic targets for disease modification. Continued collaboration between clinical and pre-clinical researchers is necessary to bridge the knowledge gaps surrounding the origin, cause, and multifaceted nature of MSA. Moreover, further work is needed towards the identification of early biomarkers for MSA, not only for better diagnostic aspects, but to implement future disease modifying therapies at an early stage.

Open Access This article is licensed under a Creative Commons Attribution 4.0 International License, which permits use, sharing, adaptation, distribution and reproduction in any medium or format, as long as you give appropriate credit to the original author(s) and the source, provide a link to the Creative Commons licence, and indicate if changes were made. The images or other third party material in this article are included in the article's Creative Commons licence, unless indicated otherwise in a credit line to the material. If material is not included in the article's Creative Commons licence and your intended use is not permitted by statutory regulation or exceeds the permitted use, you will need to obtain permission directly from the copyright holder. To view a copy of this licence, visit http://creativecommons.org/licenses/by/4.0/.

\section{References}

Adams R, van Bogaert L, van der Eecken H (1961) Dégénérescences nigro-striées et cerebello-nigro-striées; pp. 219-232. Euro Neurol 142(4): 219-232.

Al-Chalabi A, Durr A, Wood NW, Parkinson MH, Camuzat A, Hulot JS, Morrison KE, Renton A, Sussmuth SD, Landwehrmeyer BG, Ludolph A, Agid Y, Brice A, Leigh PN, Bensimon G, N. G. S. Group (2009). "Genetic variants of the alpha-synuclein gene SNCA are associated with multiple system atrophy. PLoS One 4(9): e7114.

Aoki N, Boyer PJ, Lund C, Lin WL, Koga S, Ross OA, Weiner M, Lipton A, Powers JM, White CL 3rd, Dickson DW (2015) Atypical multiple system atrophy is a new subtype of frontotemporal lobar degeneration: frontotemporal lobar degeneration associated with alpha-synuclein. Acta Neuropathol 130(1):93-105

Asi YT, Simpson JE, Heath PR, Wharton SB, Lees AJ, Revesz T, Houlden H, Holton JL (2014) Alpha-synuclein mRNA expression in oligodendrocytes in MSA. Glia 62(6):964-970

Barca E, Kleiner G, Tang G, Ziosi M, Tadesse S, Masliah E, Louis ED, Faust P, Kang UJ, Torres J, Cortes EP, Vonsattel JP, Kuo SH, Quinzii CM (2016) Decreased coenzyme Q10 levels in multiple system atrophy cerebellum. J Neuropathol Exp Neurol 75(7):663-672

Bassil F, Guerin PA, Dutheil N, Li Q, Klugmann M, Meissner WG, Bezard E, Fernagut PO (2017) Viral-mediated oligodendroglial alpha-synuclein expression models multiple system atrophy. Mov Disord 32(8):1230-1239
Batla A, De Pablo-Fernandez E, Erro R, Reich M, Calandra-Buonaura G, Barbosa P, Balint B, Ling H, Islam S, Cortelli P, Volkmann J, Quinn N, Holton JL, Warner TT, Bhatia KP (2018) Young-onset multiple system atrophy: Clinical and pathological features. Mov Disord 33(7):1099-1107

Ben-Shlomo Y, Wenning GK, Tison F, Quinn NP (1997) Survival of patients with pathologically proven multiple system atrophy: a meta-analysis. Neurology 48(2):384-393

Beyer K (2006) $\alpha$-Synuclein structure, posttranslational modification and alternative splicing as aggregation enhancers. Acta Neuropathol 112(3):237-251

Beyer K, Ariza A (2007) Protein aggregation mechanisms in synucleinopathies: commonalities and differences. J Neuropathol Exp Neurol 66(11):965-974

Boudes M, Uvin P, Pinto S, Voets T, Fowler CJ, Wenning GK, De Ridder D, Stefanova N (2013) Bladder dysfunction in a transgenic mouse model of multiple system atrophy. Mov Disord 28(3):347-355

Bousset L, Pieri L, Ruiz-Arlandis G, Gath J, Jensen PH, Habenstein B, Madiona K, Olieric V, Bockmann A, Meier BH, Melki R (2013) Structural and functional characterization of two alphasynuclein strains. Nat Commun 4:2575

Bower JH, Maraganore DM, McDonnell SK, Rocca WA (1997) Incidence of progressive supranuclear palsy and multiple system atrophy in Olmsted County, Minnesota, 1976 to 1990. Neurology 49(5):1284-1288

Bradbury S, Eggleston C (1925) Postural hypotension: a report of three cases. Am Heart J 1(1):73-86

Brundin P, Melki R (2017) Prying into the prion hypothesis for Parkinson's disease. J Neurosci 37(41):9808-9818

Cho JW, Jeon BS, Jeong D, Choi YJ, Lee JY, Lee HS, Hong SY (2008) Association between parkinsonism and participation in agriculture in Korea. J Clin Neurol 4(1):23-28

Chrysostome V, Tison F, Yekhlef F, Sourgen C, Baldi I, Dartigues JF (2004) Epidemiology of multiple system atrophy: a prevalence and pilot risk factor study in Aquitaine, France. Neuroepidemiology 23(4):201-208

Chung HK, Ho HA, Perez-Acuna D, Lee SJ (2019) Modeling alphasynuclein propagation with preformed fibril injections. J Mov Disord 12(3):139-151

Dejerine JT, AA (1900) L'atrophie olivo-ponto-cerebelleuse. Nouv Iconog de le Salpetriere 13: 330-370

Djelloul M, Holmqvist S, Boza-Serrano A, Azevedo C, Yeung MS, Goldwurm S, Frisen J, Deierborg T, Roybon L (2015) Alpha-Synuclein Expression in the oligodendrocyte lineage: an in vitro and in vivo study using rodent and human models. Stem Cell Reports 5(2):174-184

Duda JE, Giasson BI, Chen Q, Gur TL, Hurtig HI, Stern MB, Gollomp SM, Ischiropoulos H, Lee VM, Trojanowski JQ (2000a) Widespread nitration of pathological inclusions in neurodegenerative synucleinopathies. Am J Pathol 157(5):1439-1445

Duda JE, Giasson BI, Gur TL, Montine TJ, Robertson D, Biaggioni I, Hurtig HI, Stern MB, Gollomp SM, Grossman M, Lee VM, Trojanowski JQ (2000b) Immunohistochemical and biochemical studies demonstrate a distinct profile of alpha-synuclein permutations in multiple system atrophy. J Neuropathol Exp Neurol 59(9):830-841

Dutta S, Hornung S, Kruayatidee A, Maina KN, Del Rosario I, Paul KC, Wong DY, Duarte Folle A, Markovic D, Palma JA, Serrano GE, Adler CH, Perlman SL, Poon WW, Kang UJ, Alcalay RN, Sklerov M, Gylys KH, Kaufmann H, Fogel BL, Bronstein JM, Ritz B, Bitan G (2021) alpha-Synuclein in blood exosomes immunoprecipitated using neuronal and oligodendroglial markers distinguishes Parkinson's disease from multiple system atrophy. Acta Neuropathol. 
Ettle B, Reiprich S, Deusser J, Schlachetzki JC, Xiang W, Prots I, Masliah E, Winner B, Wegner M, Winkler J (2014) Intracellular alpha-synuclein affects early maturation of primary oligodendrocyte progenitor cells. Mol Cell Neurosci 62:68-78

Falcao AM, van Bruggen D, Marques S, Meijer M, Jakel S, Agirre E, Samudyata, Floriddia EM, Vanichkina DP, Ffrench-Constant C, Williams A, Guerreiro-Cacais AO, Castelo-Branco G (2018) Disease-specific oligodendrocyte lineage cells arise in multiple sclerosis. Nat Med 24(12): 1837-1844

Fanciulli A, Wenning GK (2015) Multiple-system atrophy. N Engl J Med 372(14):1375-1376

Fanciulli A, Stankovic I, Krismer F, Seppi K, Levin J, Wenning GK (2019) Multiple system atrophy. Int Rev Neurobiol 149:137-192

Fernagut PO, Diguet E, Bioulac B, Tison F (2004) MPTP potentiates 3-nitropropionic acid-induced striatal damage in mice: reference to striatonigral degeneration. Exp Neurol 185(1):47-62

Fernagut PO, Meissner WG, Biran M, Fantin M, Bassil F, Franconi JM, Tison F (2014) Age-related motor dysfunction and neuropathology in a transgenic mouse model of multiple system atrophy. Synapse 68(3):98-106

Ferreira N, Gram H, Sorrentino ZA, Gregersen E, Schmidt SI, Reimer L, Betzer C, Perez-Gozalbo C, Beltoja M, Nagaraj M, Wang J, Nowak JS, Dong M, Willen K, Cholak E, Bjerregaard-Andersen K, Mendez N, Rabadia P, Shahnawaz M, Soto C, Otzen DE, Akbey U, Meyer M, Giasson BI, Romero-Ramos M, Jensen PH (2021) Multiple system atrophy-associated oligodendroglial protein $\mathrm{p} 25 \mathrm{alpha}$ stimulates formation of novel alpha-synuclein strain with enhanced neurodegenerative potential. Acta Neuropathol.

Figueroa JJ, Singer W, Parsaik A, Benarroch EE, Ahlskog JE, Fealey RD, Parisi JE, Sandroni P, Mandrekar J, Iodice V, Low PA, Bower JH (2014) Multiple system atrophy: prognostic indicators of survival. Mov Disord 29(9):1151-1157

Flabeau O, Meissner WG, Ozier A, Berger P, Tison F, Fernagut PO (2014) Breathing variability and brainstem serotonergic loss in a genetic model of multiple system atrophy. Mov Disord 29(3):388-395

Fujioka S, Ogaki K, Tacik PM, Uitti RJ, Ross OA, Wszolek ZK (2014) Update on novel familial forms of Parkinson's disease and multiple system atrophy. Parkinsonism Relat Disord 20(Suppl 1):S29-34

Fujishiro H, Ahn TB, Frigerio R, DelleDonne A, Josephs KA, Parisi JE, Eric Ahlskog J, Dickson DW (2008) Glial cytoplasmic inclusions in neurologically normal elderly: prodromal multiple system atrophy? Acta Neuropathol 116(3):269-275

Fujiwara H, Hasegawa M, Dohmae N, Kawashima A, Masliah E, Goldberg MS, Shen J, Takio K, Iwatsubo T (2002) alpha-Synuclein is phosphorylated in synucleinopathy lesions. Nat Cell Biol 4(2):160-164

Gaig C, Iranzo A, Tolosa E, Vilaseca I, Rey MJ, Santamaria J (2008) Pathological description of a non-motor variant of multiple system atrophy. J Neurol Neurosurg Psychiatry 79(12):1399-1400

Ghorayeb I, Fernagut PO, Aubert I, Bezard E, Poewe W, Wenning GK, Tison F (2000) Toward a primate model of L-dopa-unresponsive parkinsonism mimicking striatonigral degeneration. Mov Disord 15(3):531-536

Ghorayeb I, Puschban Z, Fernagut PO, Scherfler C, Rouland R, Wenning GK, Tison F (2001) Simultaneous intrastriatal 6-hydroxydopamine and quinolinic acid injection: a model of early-stage striatonigral degeneration. Exp Neurol 167(1):133-147

Ghorayeb I, Fernagut PO, Hervier L, Labattu B, Bioulac B, Tison F (2002a) A "single toxin-double lesion" rat model of striatonigral degeneration by intrastriatal 1-methyl-4-phenylpyridinium ion injection: a motor behavioural analysis. Neuroscience 115(2):533-546
Ghorayeb I, Fernagut PO, Stefanova N, Wenning GK, Bioulac B, Tison $\mathrm{F}$ (2002b) Dystonia is predictive of subsequent altered dopaminergic responsiveness in a chronic 1-methyl-4-phenyl-1,2,3,6tetrahydropyridine +3-nitropropionic acid model of striatonigral degeneration in monkeys. Neurosci Lett 335(1):34-38

Giasson BI, Duda JE, Murray IV, Chen Q, Souza JM, Hurtig HI, Ischiropoulos H, Trojanowski JQ, Lee VM (2000) Oxidative damage linked to neurodegeneration by selective alpha-synuclein nitration in synucleinopathy lesions. Science 290(5493):985-989

Gilman S, Wenning GK, Low PA, Brooks DJ, Mathias CJ, Trojanowski JQ, Wood NW, Colosimo C, Durr A, Fowler CJ, Kaufmann H, Klockgether T, Lees A, Poewe W, Quinn N, Revesz T, Robertson D, Sandroni P, Seppi K, Vidailhet M (2008) Second consensus statement on the diagnosis of multiple system atrophy. Neurology 71(9):670-676

Glasmacher SA, Leigh PN, Saha RA (2017) Predictors of survival in progressive supranuclear palsy and multiple system atrophy: a systematic review and meta-analysis. J Neurol Neurosurg Psychiatry $88(5): 402-411$

Graham JG, Oppenheimer DR (1969) Orthostatic hypotension and nicotine sensitivity in a case of multiple system atrophy. J Neurol Neurosurg Psychiatry 32(1):28-34

Gwinn K, Devine MJ, Jin LW, Johnson J, Bird T, Muenter M, Waters C, Adler CH, Caselli R, Houlden H, Lopez G, Singleton A, Hardy J, Singleton A (2011) Clinical features, with video documentation, of the original familial lewy body parkinsonism caused by alpha-synuclein triplication (Iowa kindred). Mov Disord 26(11):2134-2136

Halliday GM (2015) Re-evaluating the glio-centric view of multiple system atrophy by highlighting the neuronal involvement. Brain 138(Pt 8):2116-2119

Halliday GM, Holton JL, Revesz T, Dickson DW (2011) Neuropathology underlying clinical variability in patients with synucleinopathies. Acta Neuropathol 122(2):187-204

Hara K, Momose Y, Tokiguchi S, Shimohata M, Terajima K, Onodera O, Kakita A, Yamada M, Takahashi H, Hirasawa M, Mizuno Y, Ogata K, Goto J, Kanazawa I, Nishizawa M, Tsuji S (2007) Multiplex families with multiple system atrophy. Arch Neurol 64(4):545-551

Hartner L, Keil TW, Kreuzer M, Fritz EM, Wenning GK, Stefanova N, Fenzl T (2016) Distinct parameters in the EEG of the PLP alpha-SYN mouse model for multiple system atrophy reinforce face validity. Front Behav Neurosci 10:252

Heckman MG, Schottlaender L, Soto-Ortolaza AI, Diehl NN, Rayaprolu S, Ogaki K, Fujioka S, Murray ME, Cheshire WP, Uitti RJ, Wszolek ZK, Farrer MJ, Sailer A, Singleton AB, Chinnery PF, Keogh MJ, Gentleman SM, Holton JL, Aoife K, Mann DM, AlSarraj S, Troakes C, Dickson DW, Houlden H, Ross OA (2014) LRRK2 exonic variants and risk of multiple system atrophy. Neurology 83(24):2256-2261

Heras-Garvin A, Stefanova N (2020) MSA: From basic mechanisms to experimental therapeutics. Parkinsonism Relat Disord 73:94-104

Heras-Garvin A, Weckbecker D, Ryazanov S, Leonov A, Griesinger C, Giese A, Wenning GK, Stefanova N (2019) Anle138b modulates alpha-synuclein oligomerization and prevents motor decline and neurodegeneration in a mouse model of multiple system atrophy. Mov Disord 34(2):255-263

Hohler AD, Singh VJ (2012) Probable hereditary multiple system atrophy-autonomic (MSA-A) in a family in the United States. J Clin Neurosci 19(3):479-480

Holec SAM and AL Woerman (2020) Evidence of distinct alpha-synuclein strains underlying disease heterogeneity. Acta Neuropathol.

Itoh K, Kasai T, Tsuji Y, Saito K, Mizuta I, Harada Y, Sudoh S, Mizuno T, Nakagawa M, Fushiki S (2014) Definite familial multiple system atrophy with unknown genetics. Neuropathology 34(3):309-313 
Jakel S, Agirre E, Mendanha Falcao A, van Bruggen D, Lee KW, Knuesel I, Malhotra D, Ffrench-Constant C, Williams A, CasteloBranco G (2019) Altered human oligodendrocyte heterogeneity in multiple sclerosis. Nature 566(7745):543-547

Jecmenica-Lukic M, Poewe W, Tolosa E, Wenning GK (2012) Premotor signs and symptoms of multiple system atrophy. Lancet Neurol 11(4):361-368

Jellinger KA (2014) Neuropathology of multiple system atrophy: new thoughts about pathogenesis. Mov Disord 29(14):1720-1741

Jellinger K (2015) Multiple system atrophy-a synucleinopathy with specific glioneuronal degeneration. Austin J Clin Neurol 2(8): 1071

Jellinger KA (2018) Multiple System Atrophy: An Oligodendroglioneural Synucleinopathy1. J Alzheimers Dis 62(3):1141-1179

Jellinger KA, Wenning GK (2016) Overlaps between multiple system atrophy and multiple sclerosis: a novel perspective. Mov Disord 31(12):1767-1771

Jeon BS, Farrer MJ, Bortnick SF, D. Korean Canadian Alliance on Parkinson's and D. Related, (2014) Mutant COQ2 in multiplesystem atrophy. N Engl J Med 371(1):80

Jin $\mathrm{H}$, Ishikawa $\mathrm{K}$, Tsunemi T, Ishiguro T, Amino T, Mizusawa $\mathrm{H}$ (2008) Analyses of copy number and mRNA expression level of the alpha-synuclein gene in multiple system atrophy. J Med Dent Sci 55(1):145-153

Kahle PJ, Neumann M, Ozmen L, Muller V, Jacobsen H, Spooren W, Fuss B, Mallon B, Macklin WB, Fujiwara H, Hasegawa M, Iwatsubo T, Kretzschmar HA, Haass C (2002) Hyperphosphorylation and insolubility of alpha-synuclein in transgenic mouse oligodendrocytes. EMBO Rep 3(6):583-588

Kaji S, Maki T, Kinoshita H, Uemura N, Ayaki T, Kawamoto Y, Furuta T, Urushitani M, Hasegawa M, Kinoshita Y, Ono Y, Mao X, Quach TH, Iwai K, Dawson VL, Dawson TM, Takahashi R (2018) Pathological endogenous alpha-synuclein accumulation in oligodendrocyte precursor cells potentially induces inclusions in multiple system atrophy. Stem Cell Reports 10(2):356-365

Katzeff JS, Phan K, Purushothuman S, Halliday GM, Kim WS (2019) Cross-examining candidate genes implicated in multiple system atrophy. Acta Neuropathol Commun 7(1):117

Kaufmann H, Norcliffe-Kaufmann L, Palma JA, Biaggioni I, Low PA, Singer W, Goldstein DS, Peltier AC, Shibao CA, Gibbons CH, Freeman R, Robertson D, Autonomic Disorders C (2017) Natural history of pure autonomic failure: A United States prospective cohort. Ann Neurol 81(2):287-297

Kiely AP, Asi YT, Kara E, Limousin P, Ling H, Lewis P, Proukakis C, Quinn N, Lees AJ, Hardy J, Revesz T, Houlden H, Holton JL (2013) alpha-Synucleinopathy associated with G51D SNCA mutation: a link between Parkinson's disease and multiple system atrophy? Acta Neuropathol 125(5):753-769

Kiely AP, Ling H, Asi YT, Kara E, Proukakis C, Schapira AH, Morris HR, Roberts HC, Lubbe $\mathrm{S}$, Limousin P, Lewis PA, Lees AJ, Quinn N, Hardy J, Love S, Revesz T, Houlden H, Holton JL (2015) Distinct clinical and neuropathological features of G51D SNCA mutation cases compared with SNCA duplication and H50Q mutation. Mol Neurodegener 10:41

Kim HJ, Jeon BS, Lee JY, Yun JY (2011) Survival of Korean patients with multiple system atrophy. Mov Disord 26(5):909-912

Kirchhof K, Apostolidis AN, Mathias CJ, Fowler CJ (2003) Erectile and urinary dysfunction may be the presenting features in patients with multiple system atrophy: a retrospective study. Int J Impot Res 15(4):293-298

Kisos H, Pukass K, Ben-Hur T, Richter-Landsberg C, Sharon R (2012) Increased neuronal alpha-synuclein pathology associates with its accumulation in oligodendrocytes in mice modeling alphasynucleinopathies. PLoS One 7(10): e46817.

Kollensperger M, Stefanova N, Reindl M, Poewe W, Wenning GK (2007) Loss of dopaminergic responsiveness in a double lesion rat model of the Parkinson variant of multiple system atrophy. Mov Disord 22(3):353-358

Kollensperger M, Geser F, Ndayisaba JP, Boesch S, Seppi K, Ostergaard K, Dupont E, Cardozo A, Tolosa E, Abele M, Klockgether T, Yekhlef F, Tison F, Daniels C, Deuschl G, Coelho M, Sampaio C, Bozi M, Quinn N, Schrag A, Mathias CJ, Fowler C, Nilsson CF, Widner H, Schimke N, Oertel W, Del Sorbo F, Albanese A, Pellecchia MT, Barone P, Djaldetti R, Colosimo C, Meco G, Gonzalez-Mandly A, Berciano J, Gurevich T, Giladi N, Galitzky M, Rascol O, Kamm C, Gasser T, Siebert U, Poewe W, Wenning GK, Emsa SG (2010) Presentation, diagnosis, and management of multiple system atrophy in Europe: final analysis of the European multiple system atrophy registry. Mov Disord 25(15):2604-2612

Kovacs GG, Laszlo L, Kovacs J, Jensen PH, Lindersson E, Botond G, Molnar T, Perczel A, Hudecz F, Mezo G, Erdei A, Tirian L, Lehotzky A, Gelpi E, Budka H, Ovadi J (2004) Natively unfolded tubulin polymerization promoting protein TPPP/p25 is a common marker of alpha-synucleinopathies. Neurobiol Dis $17(2): 155-162$

Kragh CL, Lund LB, Febbraro F, Hansen HD, Gai WP, El-Agnaf O, Richter-Landsberg C, Jensen PH (2009) Alpha-synuclein aggregation and Ser-129 phosphorylation-dependent cell death in oligodendroglial cells. J Biol Chem 284(15):10211-10222

Kuzdas D, Stemberger S, Gaburro S, Stefanova N, Singewald N, Wenning GK (2013) Oligodendroglial alpha-synucleinopathy and MSA-like cardiovascular autonomic failure: experimental evidence. Exp Neurol 247:531-536

Langston W (1936) ORTHOSTATIC HYPOTENSION; REPORT OF A CASE. Ann Intern Med 10(5):688-695

Lee PH, Kim JW, Bang OY, Ahn YH, Joo IS, Huh K (2008) Autologous mesenchymal stem cell therapy delays the progression of neurological deficits in patients with multiple system atrophy. Clin Pharmacol Ther 83(5):723-730

Lee PH, Lee JE, Kim HS, Song SK, Lee HS, Nam HS, Cheong JW, Jeong Y, Park HJ, Kim DJ, Nam CM, Lee JD, Kim HO, Sohn YH (2012) A randomized trial of mesenchymal stem cells in multiple system atrophy. Ann Neurol 72(1):32-40

Lee K, Nguyen KD, Sun C, Liu M, Zafar F, Saetern J, Flierl A, Tetrud JW, Langston JW, Dickson D, Schule B (2018) LRRK2 p.Ile1371Val Mutation in a case with neuropathologically confirmed multi-system atrophy. J Parkinsons Dis 8(1):93-100

Lin CH, Tan EK, Yang CC, Yi Z, Wu RM (2015) COQ2 gene variants associate with cerebellar subtype of multiple system atrophy in Chinese. Mov Disord 30(3):436-437

Linder J, Stenlund H, Forsgren L (2010) Incidence of Parkinson's disease and parkinsonism in northern Sweden: a populationbased study. Mov Disord 25(3):341-348

Lindersson E, Lundvig D, Petersen C, Madsen P, Nyengaard JR, Hojrup P, Moos T, Otzen D, Gai WP, Blumbergs PC, Jensen PH (2005) p25alpha stimulates alpha-synuclein aggregation and is co-localized with aggregated alpha-synuclein in alphasynucleinopathies. J Biol Chem 280(7):5703-5715

Ling H, Asi YT, Petrovic IN, Ahmed Z, Prashanth LK, Hazrati LN, Nishizawa M, Ozawa T, Lang A, Lees AJ, Revesz T, Holton JL (2015) Minimal change multiple system atrophy: an aggressive variant? Mov Disord 30(7):960-967

Low PA, Reich SG, Jankovic J, Shults CW, Stern MB, Novak P, Tanner CM, Gilman S, Marshall FJ, Wooten F, Racette B, Chelimsky T, Singer W, Sletten DM, Sandroni P, Mandrekar J (2015) Natural history of multiple system atrophy in the USA: a prospective cohort study. Lancet Neurol 14(7):710-719

Lu J-Q, Fan Y, Mitha AP, Bell R, Metz L, Moore GRW, Yong VW (2009) Association of $\alpha$-synuclein immunoreactivity with inflammatory activity in multiple sclerosis lesions. J Neuropathol Exp Neurol 68(2):179-189 
Mandel RJ, Marmion DJ, Kirik D, Chu Y, Heindel C, McCown T, Gray SJ, Kordower JH (2017) Novel oligodendroglial alpha synuclein viral vector models of multiple system atrophy: studies in rodents and nonhuman primates. Acta Neuropathol Commun 5(1):47

Marmion DJ, Rutkowski AA, Chatterjee D, Hiller BM, Werner MH, Bezard E, Kirik D, McCown T, Gray SJ, Kordower JH (2021) Viral-based rodent and nonhuman primate models of multiple system atrophy: Fidelity to the human disease. Neurobiol Dis 148: 105184.

Masuda-Suzukake M, Nonaka T, Hosokawa M, Oikawa T, Arai T, Akiyama H, Mann DM, Hasegawa M (2013) Prion-like spreading of pathological alpha-synuclein in brain. Brain $136(\mathrm{Pt}$ 4): $1128-1138$

Matsuo A, Akiguchi I, Lee GC, McGeer EG, McGeer PL, Kimura J (1998) Myelin degeneration in multiple system atrophy detected by unique antibodies. Am J Pathol 153(3):735-744

Mavroeidi P, Arvanitaki F, Karakitsou AK, Vetsi M, Kloukina I, Zweckstetter M, Giller K, Becker S, Sorrentino ZA, Giasson BI, Jensen PH, Stefanis L, Xilouri M (2019) Endogenous oligodendroglial alpha-synuclein and TPPP/p25alpha orchestrate alphasynuclein pathology in experimental multiple system atrophy models. Acta Neuropathol 138(3):415-441

May VE, Ettle B, Poehler AM, Nuber S, Ubhi K, Rockenstein E, Winner B, Wegner M, Masliah E, Winkler J (2014) alpha-Synuclein impairs oligodendrocyte progenitor maturation in multiple system atrophy. Neurobiol Aging 35(10):2357-2368

May S, Gilman S, Sowell BB, Thomas RG, Stern MB, Colcher A, Tanner CM, Huang N, Novak P, Reich SG, Jankovic J, Ondo WG, Low PA, Sandroni P, Lipp A, Marshall FJ, Wooten F, Shults CW, G. North American Multiple System Atrophy Study (2007) Potential outcome measures and trial design issues for multiple system atrophy. Mov Disord 22(16): 2371-2377

Meissner WG, Traon AP, Foubert-Samier A, Galabova G, Galitzky M, Kutzelnigg A, Laurens B, Luhrs P, Medori R, Peran P, Sabatini U, Vergnet S, Volc D, Poewe W, Schneeberger A, Staffler G, Rascol O, Investigators AFFS (2020) A phase 1 randomized trial of specific active alpha-synuclein immunotherapies PD01A and PD03A in multiple system atrophy. Mov Disord 35(11):1957-1965

Messing Z (1930) Atrophie olivo-ponto-cérébelleuse dans un cas de maladie de Parkinson. Rev Neurol (paris) 60:498-499

Meszaros L, Riemenschneider MJ, Gassner H, Marxreiter F, von Horsten S, Hoffmann A, Winkler J (2021) Human alpha-synuclein overexpressing MBP29 mice mimic functional and structural hallmarks of the cerebellar subtype of multiple system atrophy. Acta Neuropathol Commun 9(1):68

Miller DW, Johnson JM, Solano SM, Hollingsworth ZR, Standaert DG, Young AB (2005) Absence of alpha-synuclein mRNA expression in normal and multiple system atrophy oligodendroglia. J Neural Transm (vienna) 112(12):1613-1624

Mitsui J, Matsukawa T, Sasaki H, Yabe I, Matsushima M, Durr A, Brice A, Takashima H, Kikuchi A, Aoki M, Ishiura H, Yasuda T, Date H, Ahsan B, Iwata A, Goto J, Ichikawa Y, Nakahara Y, Momose Y, Takahashi Y, Hara K, Kakita A, Yamada M, Takahashi $\mathrm{H}$, Onodera O, Nishizawa M, Watanabe H, Ito M, Sobue G, Ishikawa K, Mizusawa H, Kanai K, Hattori T, Kuwabara S, Arai K, Koyano S, Kuroiwa Y, Hasegawa K, Yuasa T, Yasui K, Nakashima K, Ito H, Izumi Y, Kaji R, Kato T, Kusunoki S, Osaki Y, Horiuchi M, Kondo T, Murayama S, Hattori N, Yamamoto M, Murata M, Satake W, Toda T, Filla A, Klockgether T, Wullner U, Nicholson G, Gilman S, Tanner CM, Kukull WA, Stern MB, Lee VM, Trojanowski JQ, Masliah E, Low PA, Sandroni P, Ozelius LJ, Foroud T, Tsuji S (2015) Variants associated with
Gaucher disease in multiple system atrophy. Ann Clin Transl Neurol 2(4):417-426

Monzio Compagnoni G, Kleiner G, Samarani M, Aureli M, Faustini G, Bellucci A, Ronchi D, Bordoni A, Garbellini M, Salani S, Fortunato F, Frattini E, Abati E, Bergamini C, Fato R, Tabano S, Miozzo M, Serratto G, Passafaro M, Deleidi M, Silipigni R, Nizzardo M, Bresolin N, Comi GP, Corti S, Quinzii CM, Di Fonzo A (2018) Mitochondrial dysregulation and impaired autophagy in iPSC-derived dopaminergic neurons of multiple system atrophy. Stem Cell Reports 11(5):1185-1198

Multiple-System Atrophy Research Collaboration (2013) Mutations in COQ2 in familial and sporadic multiple-system atrophy. N Engl J Med 369(3):233-244

Nakamoto FK, Okamoto S, Mitsui J, Sone T, Ishikawa M, Yamamoto Y, Kanegae Y, Nakatake Y, Imaizumi K, Ishiura H, Tsuji S, Okano H (2018) The pathogenesis linked to coenzyme Q10 insufficiency in iPSC-derived neurons from patients with multiple-system atrophy. Sci Rep 8(1):14215

Nee LE, Gomez MR, Dambrosia J, Bale S, Eldridge R, Polinsky RJ (1991) Environmental-occupational risk factors and familial associations in multiple system atrophy: a preliminary investigation. Clin Auton Res 1(1):9-13

Nishie M, Mori F, Yoshimoto M, Takahashi H, Wakabayashi K (2004) A quantitative investigation of neuronal cytoplasmic and intranuclear inclusions in the pontine and inferior olivary nuclei in multiple system atrophy. Neuropathol Appl Neurobiol 30(5):546-554

Nykjaer CH, Brudek T, Salvesen L, Pakkenberg B (2017) Changes in the cell population in brain white matter in multiple system atrophy. Mov Disord 32(7):1074-1082

Ogaki K, Fujioka S, Heckman MG, Rayaprolu S, Soto-Ortolaza AI, Labbe C, Walton RL, Lorenzo-Betancor O, Wang X, Asmann Y, Rademakers R, Graff-Radford N, Uitti R, Cheshire WP, Wszolek ZK, Dickson DW, Ross OA (2014) Analysis of COQ2 gene in multiple system atrophy. Mol Neurodegener 9:44

Orosz F, Kovacs GG, Lehotzky A, Olah J, Vincze O, Ovadi J (2004) TPPP/p25: from unfolded protein to misfolding disease: prediction and experiments. Biol Cell 96(9):701-711

O'Sullivan SS, Massey LA, Williams DR, Silveira-Moriyama L, Kempster PA, Holton JL, Revesz T, Lees AJ (2008) Clinical outcomes of progressive supranuclear palsy and multiple system atrophy. Brain 131(Pt 5):1362-1372

Ovadi J, Orosz F (2009) An unstructured protein with destructive potential: TPPP/p25 in neurodegeneration. BioEssays 31(6):676-686

Ozawa T, Paviour D, Quinn NP, Josephs KA, Sangha H, Kilford L, Healy DG, Wood NW, Lees AJ, Holton JL, Revesz T (2004) The spectrum of pathological involvement of the striatonigral and olivopontocerebellar systems in multiple system atrophy: clinicopathological correlations. Brain 127(Pt 12):2657-2671

Ozawa T, Tada M, Kakita A, Onodera O, Tada M, Ishihara T, Morita T, Shimohata T, Wakabayashi K, Takahashi H, Nishizawa M (2010) The phenotype spectrum of Japanese multiple system atrophy. J Neurol Neurosurg Psychiatry 81(11):1253-1255

Ozawa T, Revesz T, Paviour D, Lees AJ, Quinn N, Tada M, Kakita A, Onodera O, Wakabayashi K, Takahashi H, Nishizawa M, Holton JL (2012) Difference in MSA phenotype distribution between populations: genetics or environment? J Parkinsons Dis 2(1):7-18

Palma J-A, Martinez J, Barnes E, Simon S, Norcliffe-Kaufmann L, Kaufmann H (2019) A futility trial of sirolimus in multiple system atrophy: protocol, recruitment and preliminary adverse event profile (P3.8-019). Neurology 92(15 Supplement): P3.8-019.

Panicker JN, Simeoni S, Miki Y, Batla A, Iodice V, Holton JL, Sakakibara R, Warner TT (2020) Early presentation of urinary 
retention in multiple system atrophy: can the disease begin in the sacral spinal cord? J Neurol 267(3):659-664

Papapetropoulos S, Tuchman A, Laufer D, Papatsoris AG, Papapetropoulos N, Mash DC (2007) Causes of death in multiple system atrophy. J Neurol Neurosurg Psychiatry 78(3):327-329

Papatsoris AG, Papapetropoulos S, Singer C, Deliveliotis C (2008) Urinary and erectile dysfunction in multiple system atrophy (MSA). Neurourol Urodyn 27(1):22-27

Papp MI, Lantos PL (1994) The distribution of oligodendroglial inclusions in multiple system atrophy and its relevance to clinical symptomatology. Brain 117(Pt 2):235-243

Papp MI, Kahn JE, Lantos PL (1989) Glial cytoplasmic inclusions in the CNS of patients with multiple system atrophy (striatonigral degeneration, olivopontocerebellar atrophy and Shy-Drager syndrome). J Neurol Sci 94(1-3):79-100

Park HJ, Bang G, Lee BR, Kim HO, Lee PH (2011) Neuroprotective effect of human mesenchymal stem cells in an animal model of double toxin-induced multiple system atrophy parkinsonism. Cell Transplant 20(6):827-835

Pasanen P, Myllykangas L, Siitonen M, Raunio A, Kaakkola S, Lyytinen J, Tienari PJ, Poyhonen M, Paetau A (2014) Novel alphasynuclein mutation A53E associated with atypical multiple system atrophy and Parkinson's disease-type pathology. Neurobiol Aging 35(9): 2180 e2181-2185.

Peelaerts W, Bousset L, Van der Perren A, Moskalyuk A, Pulizzi R, Giugliano M, Van den Haute C, Melki R, Baekelandt V (2015) alpha-Synuclein strains cause distinct synucleinopathies after local and systemic administration. Nature 522(7556):340-344

Peelaerts W, Brito F, Van den Haute C, Barber Janer A, Steiner J, Brundin P, Baekelandt V (2021) Widespread, specific and efficient transgene expression in oligodendrocytes after intracerebral and intracerebroventricular delivery of viral vectors in rodent brain. Hum Gene Ther.

Peng C, Gathagan RJ, Covell DJ, Medellin C, Stieber A, Robinson JL, Zhang B, Pitkin RM, Olufemi MF, Luk KC, Trojanowski JQ, Lee VM (2018) Cellular milieu imparts distinct pathological alpha-synuclein strains in alpha-synucleinopathies. Nature 557(7706):558-563

Perez-Lloret S, Flabeau O, Fernagut PO, Pavy-Le Traon A, Rey MV, Foubert-Samier A, Tison F, Rascol O, Meissner WG (2015) Current concepts in the treatment of multiple system atrophy. Mov Disord Clin Pract 2(1):6-16

Petrovic IN, Ling H, Asi Y, Ahmed Z, Kukkle PL, Hazrati LN, Lang AE, Revesz T, Holton JL, Lees AJ (2012) Multiple system atrophy-parkinsonism with slow progression and prolonged survival: a diagnostic catch. Mov Disord 27(9):1186-1190

Powell SK, Khan N, Parker CL, Samulski RJ, Matsushima G, Gray SJ, McCown TJ (2016) Characterization of a novel adeno-associated viral vector with preferential oligodendrocyte tropism. Gene Ther 23(11):807-814

Prusiner SB, Woerman AL, Mordes DA, Watts JC, Rampersaud R, Berry DB, Patel S, Oehler A, Lowe JK, Kravitz SN, Geschwind DH, Glidden DV, Halliday GM, Middleton LT, Gentleman SM, Grinberg LT, Giles K (2015) Evidence for alpha-synuclein prions causing multiple system atrophy in humans with parkinsonism. Proc Natl Acad Sci U S A 112(38):E5308-5317

Puska G, Lutz MI, Molnar K, Regelsberger G, Ricken G, Pirker W, Laszlo L, Kovacs GG (2018) Lysosomal response in relation to alpha-synuclein pathology differs between Parkinson's disease and multiple system atrophy. Neurobiol Dis 114:140-152

Quinn N (1989) Multiple system atrophy--the nature of the beast. J Neurol Neurosurg Psychiatry Suppl: 78-89.

Quinzii CM, Hirano M, DiMauro S (2014) Mutant COQ2 in multiplesystem atrophy. N Engl J Med 371(1):81-82

Recasens A, Dehay B, Bove J, Carballo-Carbajal I, Dovero S, PerezVillalba A, Fernagut PO, Blesa J, Parent A, Perier C, Farinas
I, Obeso JA, Bezard E, Vila M (2014) Lewy body extracts from Parkinson disease brains trigger alpha-synuclein pathology and neurodegeneration in mice and monkeys. Ann Neurol 75(3):351-362

Refolo V, Bez F, Polissidis A, Kuzdas-Wood D, Sturm E, Kamaratou M, Poewe W, Stefanis L, Angela Cenci M, Romero-Ramos M, Wenning GK, Stefanova N (2018) Progressive striatonigral degeneration in a transgenic mouse model of multiple system atrophy: translational implications for interventional therapies. Acta Neuropathol Commun 6(1):2

Reyes JF, Rey NL, Bousset L, Melki R, Brundin P, Angot E (2014) Alpha-synuclein transfers from neurons to oligodendrocytes. Glia 62(3):387-398

Riboldi GM, Palma JA, Cortes E, Iida MA, Sikder T, Henderson B, Raj T, Walker RH, Crary JF, Kaufmann H, Frucht S (2019) Early-onset pathologically proven multiple system atrophy with LRRK2 G2019S mutation. Mov Disord 34(7):1080-1082

Riku Y, Watanabe H, Mimuro M, Iwasaki Y, Ito M, Katsuno M, Sobue G, Yoshida M (2017) Non-motor multiple system atrophy associated with sudden death: pathological observations of autonomic nuclei. J Neurol 264(11):2249-2257

Rockenstein E, Ubhi K, Inglis C, Mante M, Patrick C, Adame A, Masliah E (2012) Neuronal to oligodendroglial alpha-synuclein redistribution in a double transgenic model of multiple system atrophy. NeuroReport 23(4):259-264

Ronchi D, Di Biase E, Franco G, Melzi V, Del Sorbo F, Elia A, Barzaghi C, Garavaglia B, Bergamini C, Fato R, Mora G, Del Bo R, Fortunato F, Borellini L, Trezzi I, Compagnoni GM, Monfrini E, Frattini E, Bonato S, Cogiamanian F, Ardolino G, Priori A, Bresolin N, Corti S, Comi GP, Di Fonzo A (2016) Mutational analysis of COQ2 in patients with MSA in Italy. Neurobiol Aging 45: 213 e211-213 e212.

Rydbirk R, Elfving B, Andersen MD, Langbol MA, Folke J, Winge K, Pakkenberg B, Brudek T, Aznar S (2017) Cytokine profiling in the prefrontal cortex of Parkinson's disease and multiple system atrophy patients. Neurobiol Dis 106:269-278

Sailer A, Scholz SW, Nalls MA, Schulte C, Federoff M, Price TR, Lees A, Ross OA, Dickson DW, Mok K, Mencacci NE, Schottlaender L, Chelban V, Ling H, O'Sullivan, Wood NW, Traynor BJ, Ferrucci L, Federoff HJ, Mhyre TR, Morris HR, Deuschl G, Quinn N, Widner H, Albanese A, Infante J, Bhatia KP, Poewe W, Oertel W, Hoglinger GU, Wullner U, Goldwurm S, Pellecchia MT, Ferreira J, Tolosa E, Bloem BR, Rascol O, Meissner WG, Hardy JA, Revesz T, Holton JL, Gasser T, Wenning GK, Singleton AB, Houlden H, G. European Multiple System Atrophy Study and U. K. M. S. A. S. G. the (2016) A genome-wide association study in multiple system atrophy. Neurology 87(15): 1591-1598

Saito Y, Matsuoka Y, Takahashi A, Ohno Y (1994) Survival of patients with multiple system atrophy. Intern Med 33(6):321-325

Salvesen L, Winge K, Brudek T, Agander TK, Lokkegaard A, Pakkenberg B (2017) Neocortical neuronal loss in patients with multiple system atrophy: a stereological study. Cereb Cortex 27(1):400-410

Scherfler C, Puschban Z, Ghorayeb I, Goebel GP, Tison F, Jellinger K, Poewe W, Wenning GK (2000) Complex motor disturbances in a sequential double lesion rat model of striatonigral degeneration (multiple system atrophy). Neuroscience 99(1):43-54

Scholz SW, Houlden H, Schulte C, Sharma M, Li A, Berg D, Melchers A, Paudel R, Gibbs JR, Simon-Sanchez J, Paisan-Ruiz C, Bras J, Ding J, Chen H, Traynor BJ, Arepalli S, Zonozi RR, Revesz T, Holton J, Wood N, Lees A, Oertel W, Wullner U, Goldwurm S, Pellecchia MT, Illig T, Riess O, Fernandez HH, Rodriguez RL, Okun MS, Poewe W, Wenning GK, Hardy JA, Singleton AB, Del Sorbo F, Schneider S, Bhatia KP, Gasser T (2009) SNCA 
variants are associated with increased risk for multiple system atrophy. Ann Neurol 65(5):610-614

Schottlaender LV, Houlden H, C. Multiple-System Atrophy Brain Bank (2014) Mutant COQ2 in multiple-system atrophy. N Engl J Med 371(1): 81

Schottlaender LV, Bettencourt C, Kiely AP, Chalasani A, Neergheen V, Holton JL, Hargreaves I, Houlden H (2016) Coenzyme Q10 Levels Are Decreased in the Cerebellum of Multiple-System Atrophy Patients. PLoS One 11(2): e0149557.

Schrag A, Ben-Shlomo Y, Quinn NP (1999) Prevalence of progressive supranuclear palsy and multiple system atrophy: a cross-sectional study. Lancet 354(9192):1771-1775

Schrag A, Wenning GK, Quinn N, Ben-Shlomo Y (2008) Survival in multiple system atrophy. Mov Disord 23(2):294-296

Schweighauser M, Shi Y, Tarutani A, Kametani F, Murzin AG, Ghetti B, Matsubara T, Tomita T, Ando T, Hasegawa K, Murayama S, Yoshida M, Hasegawa M, Scheres SHW, Goedert M (2020) Structures of alpha-synuclein filaments from multiple system atrophy. Nature 585(7825):464-469

Sharma M, Wenning G, Kruger R, G. European Multiple-System Atrophy Study (2014) Mutant COQ2 in multiple-system atrophy. N Engl J Med 371(1): 80-81

Shults CW, Rockenstein E, Crews L, Adame A, Mante M, Larrea G, Hashimoto M, Song D, Iwatsubo T, Tsuboi K, Masliah E (2005) Neurological and neurodegenerative alterations in a transgenic mouse model expressing human alpha-synuclein under oligodendrocyte promoter: implications for multiple system atrophy. J Neurosci 25(46):10689-10699

Shy GM, Drager GA (1960) A neurological syndrome associated with orthostatic hypotension: a clinical-pathologic study. Arch Neurol 2:511-527

Singer W, Dietz AB, Zeller AD, Gehrking TL, Schmelzer JD, Schmeichel AM, Gehrking JA, Suarez MD, Sletten DM, Minota Pacheco KV, Coon EA, Sandroni P, Benarroch EE, Fealey RD, Matsumoto JY, Bower JH, Hassan A, McKeon A, Windebank AJ, Mandrekar JN, Low PA (2019) Intrathecal administration of autologous mesenchymal stem cells in multiple system atrophy. Neurology 93(1):e77-e87

Soma H, Yabe I, Takei A, Fujiki N, Yanagihara T, Sasaki H (2008) Associations between multiple system atrophy and polymorphisms of SLC1A4, SQSTM1, and EIF4EBP1 genes. Mov Disord 23(8):1161-1167

Song YJ, Lundvig DM, Huang Y, Gai WP, Blumbergs PC, Hojrup P, Otzen D, Halliday GM, Jensen PH (2007) p25alpha relocalizes in oligodendroglia from myelin to cytoplasmic inclusions in multiple system atrophy. Am J Pathol 171(4):1291-1303

Spillantini MG, Crowther RA, Jakes R, Cairns NJ, Lantos PL, Goedert M (1998) Filamentous alpha-synuclein inclusions link multiple system atrophy with Parkinson's disease and dementia with Lewy bodies. Neurosci Lett 251(3):205-208

Stamler, D., M. Bradbury, C. Wong and E. Offman (2019). A first in human study of PBT434, a novel small molecule inhibitor of $\alpha$-synuclein aggregation (S4. 001), AAN Enterprises.

Stefanova N, Klimaschewski L, Poewe W, Wenning GK, Reindl M (2001) Glial cell death induced by overexpression of alphasynuclein. J Neurosci Res 65(5):432-438

Stefanova N, Emgard M, Klimaschewski L, Wenning GK, Reindl M (2002) Ultrastructure of alpha-synuclein-positive aggregations in U373 astrocytoma and rat primary glial cells. Neurosci Lett 323(1):37-40

Stefanova N, Puschban Z, Fernagut PO, Brouillet E, Tison F, Reindl M, Jellinger KA, Poewe W, Wenning GK (2003a) Neuropathological and behavioral changes induced by various treatment paradigms with MPTP and 3-nitropropionic acid in mice: towards a model of striatonigral degeneration (multiple system atrophy). Acta Neuropathol 106(2):157-166
Stefanova N, Schanda K, Klimaschewski L, Poewe W, Wenning GK, Reindl M (2003b) Tumor necrosis factor-alpha-induced cell death in U373 cells overexpressing alpha-synuclein. J Neurosci Res 73(3):334-340

Stefanova N, Lundblad M, Tison F, Poewe W, Cenci MA, Wenning GK (2004) Effects of pulsatile L-DOPA treatment in the double lesion rat model of striatonigral degeneration (multiple system atrophy). Neurobiol Dis 15(3):630-639

Stefanova N, Reindl M, Neumann M, Haass C, Poewe W, Kahle PJ, Wenning GK (2005) Oxidative stress in transgenic mice with oligodendroglial alpha-synuclein overexpression replicates the characteristic neuropathology of multiple system atrophy. Am J Pathol 166(3):869-876

Stefanova N, Reindl M, Neumann M, Kahle PJ, Poewe W, Wenning GK (2007) Microglial activation mediates neurodegeneration related to oligodendroglial alpha-synucleinopathy: implications for multiple system atrophy. Mov Disord 22(15):2196-2203

Stefanova N, Kaufmann WA, Humpel C, Poewe W, Wenning GK (2012) Systemic proteasome inhibition triggers neurodegeneration in a transgenic mouse model expressing human alpha-synuclein under oligodendrocyte promoter: implications for multiple system atrophy. Acta Neuropathol 124(1):51-65

Stemberger S, Poewe W, Wenning GK, Stefanova N (2010) Targeted overexpression of human alpha-synuclein in oligodendroglia induces lesions linked to MSA-like progressive autonomic failure. Exp Neurol 224(2):459-464

Stemberger S, Jamnig A, Stefanova N, Lepperdinger G, Reindl M, Wenning GK (2011) Mesenchymal stem cells in a transgenic mouse model of multiple system atrophy: immunomodulation and neuroprotection. PLoS One 6(5): e19808.

Tada M, Onodera O, Tada M, Ozawa T, Piao YS, Kakita A, Takahashi H, Nishizawa M (2007) Early development of autonomic dysfunction may predict poor prognosis in patients with multiple system atrophy. Arch Neurol 64(2):256-260

Tada M, Kakita A, Toyoshima Y, Onodera O, Ozawa T, Morita T, Nishizawa M, Takahashi H (2009) Depletion of medullary serotonergic neurons in patients with multiple system atrophy who succumbed to sudden death. Brain 132(Pt 7):1810-1819

Takahashi M, Tomizawa K, Ishiguro K, Sato K, Omori A, Sato S, Shiratsuchi A, Uchida T, Imahori K (1991) A novel brain-specific $25 \mathrm{kDa}$ protein (p25) is phosphorylated by a Ser/Thr-Pro kinase (TPK II) from tau protein kinase fractions. FEBS Lett 289(1):37-43

Takahashi K, Tanabe K, Ohnuki M, Narita M, Ichisaka T, Tomoda $\mathrm{K}$, Yamanaka S (2007) Induction of pluripotent stem cells from adult human fibroblasts by defined factors. Cell 131(5):861-872

Tanji K, Miki Y, Mori F, Nikaido Y, Narita H, Kakita A, Takahashi H, Wakabayashi K (2019) A mouse model of adult-onset multiple system atrophy. Neurobiol Dis 127:339-349

Tison F, Yekhlef F, Chrysostome V, Sourgen C (2000) Prevalence of multiple system atrophy. Lancet 355(9202):495-496

Torre Murazabal T, Van der Perren A, Coens A, Barber Janer A, Camacho-Garcia S, Stefanova N, Melki R, Baekelandt V, Peelaerts W (2020) $\alpha$-Synuclein strains influence multiple system atrophy via central and peripheral mechanisms. bioRxiv: 2020.2010.2016.342089.

Ubhi K, Rockenstein E, Mante M, Inglis C, Adame A, Patrick C, Whitney K, Masliah E (2010) Neurodegeneration in a transgenic mouse model of multiple system atrophy is associated with altered expression of oligodendroglial-derived neurotrophic factors. J Neurosci 30(18):6236-6246

Ubhi K, Low P, Masliah E (2011) Multiple system atrophy: a clinical and neuropathological perspective. Trends Neurosci 34(11):581-590

Uemura N, Uemura MT, Lo A, Bassil F, Zhang B, Luk KC, Lee VM, Takahashi R, Trojanowski JQ (2019) Slow progressive 
accumulation of oligodendroglial alpha-synuclein (alpha-Syn) pathology in synthetic alpha-syn fibril-induced mouse models of synucleinopathy. J Neuropathol Exp Neurol 78(10):877-890

Valera E, Spencer B, Mott J, Trejo M, Adame A, Mante M, Rockenstein E, Troncoso JC, Beach TG, Masliah E, Desplats P (2017) MicroRNA-101 modulates autophagy and oligodendroglial alpha-synuclein accumulation in multiple system atrophy. Front Mol Neurosci 10:329

Van der Eecken H (1960) Striopallidal-nigral degeneration. An hitherto undescribed lesion in paralysis agitans. J Neuropathol Exp Neurol 19:159-161

Van der Perren A, Gelders G, Fenyi A, Bousset L, Brito F, Peelaerts W, Van den Haute C, Gentleman S, Melki R, Baekelandt V (2020) The structural differences between patient-derived alphasynuclein strains dictate characteristics of Parkinson's disease, multiple system atrophy and dementia with Lewy bodies. Acta Neuropathol 139(6):977-1000

Vanacore N (2005) Epidemiological evidence on multiple system atrophy. J Neural Transm (vienna) 112(12):1605-1612

Vanacore N, Bonifati V, Fabbrini G, Colosimo C, Marconi R, Nicholl D, Bonuccelli U, Stocchi F, Lamberti P, Volpe G, De Michele G, Iavarone I, Bennett P, Vieregge P, Meco G (2000) Smoking habits in multiple system atrophy and progressive supranuclear palsy. European Study Group on Atypical Parkinsonisms. Neurology 54(1):114-119

Vanacore N, Bonifati V, Fabbrini G, Colosimo C, De Michele G, Marconi R, Stocchi F, Nicholl D, Bonuccelli U, De Mari M, Vieregge P, Meco G, E. Consortium (2005). "Case-control study of multiple system atrophy." Mov Disord 20(2): 158-163

Vidal JS, Vidailhet M, Elbaz A, Derkinderen P, Tzourio C, Alperovitch A (2008) Risk factors of multiple system atrophy: a case-control study in French patients. Mov Disord 23(6):797-803

Vidal JS, Vidailhet M, Derkinderen P, Tzourio C, Alperovitch A (2010) Familial aggregation in atypical Parkinson's disease: a case control study in multiple system atrophy and progressive supranuclear palsy. J Neurol 257(8):1388-1393

Villumsen M, Aznar S, Pakkenberg B, Jess T, Brudek T (2019) Inflammatory bowel disease increases the risk of Parkinson's disease: a Danish nationwide cohort study 1977-2014. Gut 68(1):18-24

Wakabayashi K, Takahashi H (2006) Cellular pathology in multiple system atrophy. Neuropathology 26(4):338-345

Wakabayashi K, Mori F, Nishie M, Oyama Y, Kurihara A, Yoshimoto M, Kuroda N (2005) An autopsy case of early ("minimal change") olivopontocerebellar atrophy (multiple system atrophycerebellar). Acta Neuropathol 110(2):185-190

Waldner R, Puschban Z, Scherfler C, Seppi K, Jellinger K, Poewe W, Wenning GK (2001) No functional effects of embryonic neuronal grafts on motor deficits in a 3-nitropropionic acid rat model of advanced striatonigral degeneration (multiple system atrophy). Neuroscience 102(3):581-592

Watanabe H, Saito Y, Terao S, Ando T, Kachi T, Mukai E, Aiba I, Abe Y, Tamakoshi A, Doyu M, Hirayama M, Sobue G (2002) Progression and prognosis in multiple system atrophy: an analysis of 230 Japanese patients. Brain 125(Pt 5):1070-1083

Watanabe H, Riku Y, Nakamura T, Hara K, Ito M, Hirayama M, Yoshida M, Katsuno M, Sobue G (2016) Expanding concept of clinical conditions and symptoms in multiple system atrophy. Rinsho Shinkeigaku 56(7):457-464

Watts JC, Giles K, Oehler A, Middleton L, Dexter DT, Gentleman SM, DeArmond SJ, Prusiner SB (2013) Transmission of multiple system atrophy prions to transgenic mice. Proc Natl Acad Sci USA 110(48):19555-19560

Wenning GK, Ben Shlomo Y, Magalhaes M, Daniel SE, Quinn NP (1994a) Clinical features and natural history of multiple system atrophy. An analysis of 100 cases. Brain 117(Pt 4):835-845
Wenning GK, Quinn N, Magalhaes M, Mathias C, Daniel SE (1994b) "Minimal change" multiple system atrophy. Mov Disord 9(2):161-166

Wenning GK, Granata R, Laboyrie PM, Quinn NP, Jenner P, Marsden CD (1996) Reversal of behavioural abnormalities by fetal allografts in a novel rat model of striatonigral degeneration. Mov Disord 11(5):522-532

Wenning GK, Tison F, Ben Shlomo Y, Daniel SE, Quinn NP (1997) Multiple system atrophy: a review of 203 pathologically proven cases. Mov Disord 12(2):133-147

Wenning GK, Stefanova N, Jellinger KA, Poewe W, Schlossmacher MG (2008) Multiple system atrophy: a primary oligodendrogliopathy. Ann Neurol 64(3):239-246

Wenning GK, Geser F, Krismer F, Seppi K, Duerr S, Boesch S, Kollensperger M, Goebel G, Pfeiffer KP, Barone P, Pellecchia MT, Quinn NP, Koukouni V, Fowler CJ, Schrag A, Mathias CJ, Giladi N, Gurevich N, Dupont E, Ostergaard K, Nilsson CF, Widner H, Oertel W, Eggert KM, Albanese A, del Sorbo F, Tolosa E, Cardozo A, Deuschl G, Hellriegel H, Klockgether T, Dodel R, Sampaio C, Coelho M, Djaldetti R, Melamed E, Gasser T, Kamm C, Meco G, Colosimo C, Rascol O, Meissner WG, Tison F, Poewe W, G. European Multiple System Atrophy Study (2013) The natural history of multiple system atrophy: a prospective European cohort study. Lancet Neurol 12(3): 264-274

Williams GP, Marmion DJ, Schonhoff AM, Jurkuvenaite A, Won WJ, Standaert DG, Kordower JH, Harms AS (2020) T cell infiltration in both human multiple system atrophy and a novel mouse model of the disease. Acta Neuropathol 139(5):855-874

Winter Y, Bezdolnyy Y, Katunina E, Avakjan G, Reese JP, Klotsche J, Oertel WH, Dodel R, Gusev E (2010) Incidence of Parkinson's disease and atypical parkinsonism: Russian population-based study. Mov Disord 25(3):349-356

Woerman AL, Stohr J, Aoyagi A, Rampersaud R, Krejciova Z, Watts JC, Ohyama T, Patel S, Widjaja K, Oehler A, Sanders DW, Diamond MI, Seeley WW, Middleton LT, Gentleman SM, Mordes DA, Sudhof TC, Giles K, Prusiner SB (2015) Propagation of prions causing synucleinopathies in cultured cells. Proc Natl Acad Sci U S A 112(35):E4949-4958

Woerman AL, Oehler A, Kazmi SA, Lee J, Halliday GM, Middleton LT, Gentleman SM, Mordes DA, Spina S, Grinberg LT, Olson SH, Prusiner SB (2019) Multiple system atrophy prions retain strain specificity after serial propagation in two different $\operatorname{Tg}\left(\mathrm{SNCA}^{*} \mathrm{~A} 53 \mathrm{~T}\right)$ mouse lines. Acta Neuropathol 137(3):437-454

Woerman AL, Watts JC, Aoyagi A, Giles K, Middleton LT, Prusiner SB (2018) alpha-Synuclein: Multiple System Atrophy Prions. Cold Spring Harb Perspect Med 8(7).

Wullner U, Abele M, Schmitz-Huebsch T, Wilhelm K, Benecke R, Deuschl G, Klockgether T (2004) Probable multiple system atrophy in a German family. J Neurol Neurosurg Psychiatry 75(6):924-925

Wullner U, Schmitz-Hubsch T, Abele M, Antony G, Bauer P, Eggert K (2007) Features of probable multiple system atrophy patients identified among 4770 patients with parkinsonism enrolled in the multicentre registry of the German Competence Network on Parkinson's disease. J Neural Transm (vienna) 114(9):1161-1165

Xia C, Postuma RB (2020) Diagnosing multiple system atrophy at the prodromal stage. Clin Auton Res 30(3):197-205

Xie T, Kang UJ, Kuo SH, Poulopoulos M, Greene P, Fahn S (2015) Comparison of clinical features in pathologically confirmed PSP and MSA patients followed at a tertiary center. NPJ Parkinsons Dis 1:15007

Yabe I, Soma H, Takei A, Fujiki N, Yanagihara T, Sasaki H (2006) MSA-C is the predominant clinical phenotype of MSA in Japan: analysis of 142 patients with probable MSA. J Neurol Sci 249(2):115-121 
Yazawa I, Giasson BI, Sasaki R, Zhang B, Joyce S, Uryu K, Trojanowski JQ, Lee VM (2005) Mouse model of multiple system atrophy alpha-synuclein expression in oligodendrocytes causes glial and neuronal degeneration. Neuron 45(6):847-859

Yoshida M (2007) Multiple system atrophy: alpha-synuclein and neuronal degeneration. Neuropathology 27(5):484-493

Yu Z, Shi M, Stewart T, Fernagut PO, Huang Y, Tian C, Dehay B, Atik A, Yang D, De Giorgi F, Ichas F, Canron MH, Ceravolo R, Frosini D, Kim HJ, Feng T, Meissner WG, Zhang J (2020) Reduced oligodendrocyte exosome secretion in multiple system atrophy involves SNARE dysfunction. Brain 143(6):1780-1797
Zhao Q, Yang X, Tian S, An R, Zheng J, Xu Y (2016) Association of the COQ2 V393A variant with risk of multiple system atrophy in East Asians: a case-control study and meta-analysis of the literature. Neurol Sci 37(3):423-430

Publisher's Note Springer Nature remains neutral with regard to jurisdictional claims in published maps and institutional affiliations. 